\title{
ALZHEIMER'S DISEASE MODIFIES PROGENITOR CELL EXPRESSION OF MONOAMINE OXIDASE B IN THE SUBVENTRICULAR ZONE
}

\begin{tabular}{|c|c|}
\hline Journal: & Journal of Neuroscience Research \\
\hline Manuscript ID: & jnr-2009-Aug-3169.R2 \\
\hline Wiley - Manuscript type: & Research Article \\
\hline $\begin{array}{r}\text { Date Submitted by the } \\
\text { Author: }\end{array}$ & \\
\hline Complete List of Authors: & $\begin{array}{l}\text { Pugliese, Marco; Universitat de Barcelona, Unitat de Bioquímica i } \\
\text { Biologia Molecular } \\
\text { Rodríguez, Manuel; Universitat de Barcelona, Unitat de Bioquímica i } \\
\text { Biologia molecular } \\
\text { Pujadas, Lluis; Universitat de Barcelona, Unitat de Bioquímica i } \\
\text { Biologia Molecular } \\
\text { Gimeno, Javier; Universitat de Barcelona, Unitat de Bioquímica i } \\
\text { Biologia Molecular } \\
\text { Billett, E. Ellen; Nottingham Trent University, School of Science and } \\
\text { Technology } \\
\text { Wells, Cheryl; Nottingham Trent University, School of Science and } \\
\text { Technology } \\
\text { Mahy, Nicole; Universitat de Barcelona, Unitat de Bioquímica i } \\
\text { Biologia Molecular }\end{array}$ \\
\hline Keywords: & $\begin{array}{l}\text { Astroglia, MAO (monoamine oxidase), Nestin, Neural stem cells, } \\
\text { Neurogenesis }\end{array}$ \\
\hline
\end{tabular}

\section{ScholaronE \\ Manuscript Central}




\section{ALZHEIMER'S DISEASE MODIFIES PROGENITOR CELL EXPRESSION OF MONOAMINE OXIDASE B IN THE SUBVENTRICULAR ZONE}

Marco Pugliese ${ }^{1}$, Manuel J. Rodríguez ${ }^{1}$, Javier Gimeno-Bayon ${ }^{1}$, Lluís Pujadas ${ }^{1}$, Ellen E. Billett ${ }^{2}$, Cheryl Wells ${ }^{2}$ and Nicole Mahy ${ }^{1}$

(1) Unitat de Bioquímica i Biologia Molecular, Facultat de Medicina, Institut d'Investigacions Biomèdiques August Pi i Sunyer (IDIBAPS), Universitat de Barcelona and Centro de Investigación Biomédica en Red sobre Enfermedades Neurodegenerativas (CIBERNED), Barcelona, Spain

(2) School of Science and Technology, Nottingham Trent University, Clifton Lane, Nottingham, NG11 8NS, UK

* Corresponding author: Dr. Nicole Mahy

Unitat de Bioquímica

Fac. Medicina, UB.

c/ Casanova, 143

08036 Barcelona, SPAIN

TEL: +34934024525

FAX: +349340358 82

E-mail: nmahy@ub.edu

Running title: AD modifies MAO-B expression in the SVZ

\section{GRANT INFORMATION}

Grant SAF2008-01902 by Ministerio de Ciencia e Innovación (Spain)

Grant 2009SGR1380 by Generalitat de Catalunya (Spain) 


\begin{abstract}
In the adult brain, progenitor cells remaining in the subventricular zone (SVZ) are frequently identified as glial fibrillary acidic protein (GFAP)- positive cells that retain attributes reminiscent of radial glia. Because the very high expression of monoamine oxidase $\mathrm{B}$ (MAO-B) in the subventricular area has been related to epithelial and astroglial expression, we aimed to ascertain whether it was also expressed by progenitor cells of human control and Alzheimer's disease (AD) patients. In the SVZ epithelial cells and astrocyte-like cells presented rich MAO-B activity and immunolabeling. Nestin-positive cells were found in the same area showing a radial-glia-like morphology. When co-immunostaining and confocal microscopy were performed, most nestin-positive cells showed MAO-B activity and labeling. The increased progenitor activity in SVZ proposed in AD patients was confirmed by the positive correlation between the SVZ nestin/MAO-B ratio and the progression of the disease. Nestin/GFAP positive cells, devoid of MAO-B can represent a distinct subpopulation of an earlier phase of maturation. This would indicate that MAO-B expression takes place in a further step of nestin/GFAP positive cells differentiation. In the early AD stages, the discrete MAO-B reduction, different from the severe GFAP decrease would reflect the capacity of this population of MAO-B positive progenitor cells to adapt to the neurodegenerative process.
\end{abstract}

Keywords: Astroglia; MAO-B; Nestin; Neural Stem cells; neurogenesis. 


\section{INTRODUCTION}

Neural progenitor/stem cells characterized in adult human brain possess the characteristics of self-renewal, proliferation and differentiation along all major neural lineages. (Gross, 2000; Lie et al., 2004; Taupin, 2006). Their development progress in a permissive microenvironment and proceeds in several stages characterized by their morphology, and by gene expression of specific markers such as glial fibrillary acidic protein (GFAP) and the intermediate filament protein nestin (Garcia et al., 2004; Imura et al., 2003; Wei et al., 2002).

In adult mammalian brain, germinal regions are the subventricular zone (SVZ) of the lateral ventricle and the subgranular zone within the dentate gyrus of the hippocampus and present abundant multipotent neural stem cells showing structural and biological markers of astroglia (Alvarez-Buylla and Garcia-Verdugo, 2002; Christie and Cameron, 2006; Ihrie and Alvarez-Buylla, 2008). In rodent, SVZ is the source of new specific type of neurons destined to the olfactory bulb (Kornack and Rakic, 2001; Lledo et al., 2008) and of oligondendrocytes during development (Levison and Goldman, 1993). Human SVZ also harbors abundant multipotent progenitor cells exhibiting markers of adult neurogenesis (Bernier et al., 2000; Bernier et al., 2002) that correspond to astrocytes (Doetsch et al., 1999; Sanai et al., 2004). In contrast to rodent, human SVZ astrocytes are not found adjacent to the ependymal layer, but forming a ribbon of cells lining the lateral ventricle, with no evidence of migrating neuroblasts (QuinonesHinojosa et al., 2006; Sanai et al., 2004).

Basic questions regarding progenitor cell biology and mechanisms of differentiation remain open. As very few markers allow differentiating a multipotent radial-glia-like stem cell from a progenitor one, it remains difficult to identify with enough criteria their 
future neuronal development. A better knowledge of the specific expression of each cell type is then needed to allow a clear discrimination.

With regard to astroglial markers, expression of GFAP has been found in human adult SVZ progenitor cells whereas the $\mathrm{S}-100 \beta$ presence is restricted to mature cells. However information concerning other well-identified astroglial markers remains elusive. Characterization of astroglial response based on monoamine oxidase B (MAOB; EC 1.4.3.4) expression has evidenced very high SVZ labeling in adult brain that could not be limited to epithelial and astroglial cells (Saura et al., 1997). With human aging, brain MAO-B activity increases progressively, beginning around the age of 5060 years (Kumar and Andersen, 2004; Saura et al., 1997), associated with increased astrogliosis. In Alzheimer's disease (AD) patients a further increased SVZ MAO-B expression has been observed (Emilsson et al., 2002; Kennedy et al., 2003; Saura et al., 1994), together with an increased SVZ progenitor activity associated with key pathological and neurochemical substrates (Ziabreva et al., 2006). In this study we investigated whether increased MAO-B expression in the SVZ of $\mathrm{AD}$ is related to endogenous proliferation and differentiation of progenitor cells. To help define the process of progenitor cell differentiation and begin approaching the underlying mechanisms present in neurodegenerative diseases, we investigated the specific expression of MAO-B in the SVZ and evaluated its relationship with specific progenitor cell and astrocyte markers in $\mathrm{AD}$ patients compared to age-matched controls.

\section{MATERIALS AND METHODS}

\section{Human post-mortem brain tissue}

Human post-mortem tissue samples of SVZ of the lateral ventricle walls corresponded to the anterior horn and body of ventricle regions were selected for this study. They 
included the head and the body of caudate nucleus (Quinones-Hinojosa et al., 2006) and were obtained from our local Neurological Tissue Bank (Serveis Cientifico-Tècnics, Universitat de Barcelona, Barcelona, Spain) according to the European ethics guidelines and approved by the appropriated Research Ethics Committee. Brains were obtained at autopsy from individuals that suffered a clinical history of $\mathrm{AD}(\mathrm{n}=7$, stages II, V, VI, aged 79-91 years) and from non-demented controls ( $n=3$, aged 44-74 years) (see Table 1 for a summary of case histories). Neuropathological confirmation of the clinical diagnosis was undertaken at the Neurological Tissue Bank according to Braak and Newell criteria (Braak and Braak, 1991; Newell et al., 1999). The investigation was carried out on tissues that were either fresh-frozen and stored at $-80^{\circ} \mathrm{C}$ or paraffinembedded; 35 serial sections where obtained from each one of them. Sections thickness was $12 \mu \mathrm{m}$ for fresh-frozen tissue and $8 \mu \mathrm{m}$ for paraffin embedded tissue. All sections were mounted in slices (one section each) and used for histological and immunohistochemical procedures.

\section{Materials}

Clorgyline hydrochloride was purchased from Research Biochemicals Inc, (USA), the Immobilon-P membranes from Millipore (Bedford, MA) and the Lumi-Light enhanced chemiluminescence ECL from Roche Diagnostics (Mannheim, Germany). The rabbit anti-nestin polyclonal antibody was purchased from CHEMICON International (Temecula CA, USA), the mouse monoclonal anti-MHC II (HLA-DR) Ab-1 (Clone LN3) from Neomarkers (Fremont CA, USA), and the mouse monoclonal anti-A $\beta_{8-17}$ was from DakoCytomation (Glostrup, Denmark). The mouse monoclonal anti-GFAP, the secondary antibodies and immunohistochemical reagents were from Sigma (St. Louis MO, USA, except for Alexa488 conjugated anti-rabbit IgG antibody and 
Alexa546 conjugated anti-mouse IgG antibody which were from Molecular Probes (Madrid, Spain).

\section{Western blot analysis of MAO-B}

Frozen $100 \mu \mathrm{g}$ samples from dissected SVZ or brain parenchyma were manually homogenized in 5 volumes of ice-cold Tris-HCl $50 \mathrm{mM}, \mathrm{pH} 7.7$ and centrifuged at $15000 \mathrm{rpm}$ for $10 \mathrm{~min}, 4^{\circ} \mathrm{C}$. The pellet was resuspended in ice cooled Tris- $\mathrm{HCl}$ and centrifuged twice more. The final pellet was resuspended in Tris- $\mathrm{HCl}$ incubation buffer. Protein content was determined by the method of Bradford using bovine serum albumin as standard. Western blot analysis was performed as previously described (Yeomanson and Billett, 1992) using the mouse monoclonal anti-MAO-B antibody 3F12/G10/2E3. Immobilon-P membranes were used for electroblotting. Blots were probed with antiMAO-B antibody (1:500, v/v) and binding was detected using an HRP-conjugated antimouse IgG antibody. Incubation with no primary antibody was used to control the specificity of results. The immunocomplexes were developed using Lumi-Light ECL.

\section{Histology and immunohistochemistry}

Nissl staining was performed according to standard procedure with cresyl violet on four sections of every paraffin-embedded tissue. MAO-B histochemistry was performed according to Arai (Arai et al., 1986). Briefly, after washing with $0.01 \mathrm{M}$ phosphate buffer saline (PBS), 5 cryostat sections of every fresh-frozen tissue were incubated in a reaction medium for $48 \mathrm{~h}$ at $4^{\circ} \mathrm{C}$. The medium consisted of $75 \mathrm{mg}$ tyramine hydrochloride, $5 \mathrm{mg}$ 3-3'-diaminobenzidine (DAB), $100 \mathrm{mg}$ horseradish peroxidase, $600 \mathrm{mg}$ nickel ammonium sulphate and $10^{-6} \mathrm{M}$ clorgyline hydrochloride for monoamine oxidase A inhibition. MAO-B activity appeared in the tissue sections as dark-blue precipitates. 
For nestin, GFAP, HLA-DR, and amyloid-beta (A $\beta)$ immunohistochemistry analysis, 12 serial paraffin-embedded SVZ sections of every brain sample were processed with the avidin-biotin peroxidase method. For $\mathrm{A} \beta$ immunohistochemistry, sections were previously incubated with $98 \%$ formic acid for 3 min to enhance antigenicity. A 30-min preincubation in $\mathrm{H}_{2} \mathrm{O}_{2}$-methanol-PBS $(0.3 / 9.7 / 90)$ was performed in all slices to inhibit non-specific staining in blood vessels and neurons. Sections were incubated at room temperature in blocking solution (0.01 M PBS $+3 \%$ normal goat serum, $0.1 \%$ Triton $\mathrm{X}$ 100) for $2 \mathrm{~h}$ and separately incubated overnight at $4^{\circ} \mathrm{C}$ with the primary antibody at the appropriated dilution in blocking solution. After washing and incubation with the appropriated biotinilated secondary antibody, sections were incubated with ExtrAvidin (1:250), and developed in DAB and $\mathrm{H}_{2} \mathrm{O}_{2}$. Some sections were counterstained with Mayer's Haematoxylin.

For MAO-B immunohistochemistry, sections were processed with the avidin-biotin peroxidase method with some modifications (Rodríguez et al., 2000). 3 serial consecutive frozen SVZ sections of every sample were post-fixed with acetone for 3 min. at room temperature. After blocking endogenous peroxidases, sections were incubated for $30 \mathrm{~min}$ at room temperature in blocking solution containing normal pig serum. Overnight incubation was performed at $4^{\circ} \mathrm{C}$ with mouse monoclonal anti-MAOB antibody (3F12/G10/2E3) (Yeomanson and Billett, 1992) diluted 1:50. Then, sections were processed as above described. In all cases, sections stained only with the secondary antibodies were used as negative controls.

According to previous anatomical classification (Quinones-Hinojosa et al., 2006) four layers were observed throughout the SVZ: a monolayer of ependymal cells (Layer I), a hypocellular gap (Layer II), a ribbon of cells (Layer III) composed of astrocytes and a transitional zone (layer IV). These Layers I-IV were observed at the optic microscope 
and 4 areas of interest of $1.0 \mathrm{~mm}^{2}$ each were randomly selected to perform the cell number estimations at a $\mathrm{x} 40$ objective magnification. This counting procedure was performed by duplicate in three different sections of every case sample. Positive cells were counted in layers I-IV from the SVZ to the parenchyma boundary, and quantification was made using the Image Pro Plus v.5.1 image and analysis system (Media Cybernetics Inc., Bethesda, MD, USA).

Double immunofluorescence was performed on 4 fresh-frozen and 4 paraffin-embedded SVZ sections of every sample. Sections were co-incubated overnight at $4^{\circ} \mathrm{C}$ with antinestin antibody and either anti-MAO-B antibody (fresh-frozen tissue), anti-GFAP antibody; or anti-HLA-DR antibody. After washing in PBS, sections were incubated in dark with a cocktail of Alexa488 conjugated anti-rabbit IgG antibody and Alexa546 conjugated anti-mouse IgG antibody. Human brain autofluorescent lipofuscin artifacts were reduced to near background levels by immersion in $70 \%$ ethanol supplemented with $1 \%$ of Sudan black B for 5 min (Schnell et al., 1999). Sections were mounted in Immuno-Fluore Mounting medium (ICN Biomedicals, Barcelona, Spain) and examined with a Leica TCS-SL confocal microscope. Counting of double-stained cells was performed as above explained for single immunohistochemistry procedures. Due to the antibody characteristics and difficult preservation of human sample integrity, no GFAP/MAO-B or GFAP/MAO-B/nestin co-localization could be performed. Because of that, to estimate the relationship between the three cell markers, a correlation analysis was performed and the ratios GFAP/MAO-B, Nestin/GFAP and Nestin/MAO-B were calculated from the cell counts assessed by single immunohistochemistry.

\section{Statistical analysis}

Kurtosis and Skewness moments were calculated to test the normal distribution of data. A one-way analysis of variance followed by the Fisher's least significant difference 
analysis was performed to detect differences. Correlations between cell markers and the progression of $\mathrm{AD}$ were estimated by regression analysis between cell counts and a numerical value assigned to each $\mathrm{AD}$ stage. All values are presented as mean \pm standard error of the mean (SD), and differences were considered to be significant at the $\mathrm{P}<0.05$ level. Data were analyzed with the statistical analysis package StatGraphics 5.0 (STSC Inc., Rockville, MD, USA).

\section{RESULTS}

\section{Characterization of human SVZ}

In all control and $\mathrm{AD}$ cases, the anterior horn region and the body of the ventricle region of human SVZ presented a similar cellular organization (Figure 1a, b) as published elsewere (Quinones-Hinojosa et al., 2006). Ependymal cells were arranged as a one-cell thick epithelium forming Layer I. Layer II, an hypocellular region, formed a gap between Layer I and a dense ribbon of cell bodies (layer III of the SVZ) of different size and morphology. Layer IV was observed as a transitional zone to the striatal brain parenchyma.

GFAP immunohistochemistry revealed an abundance of GFAP positive processes within the hypocellular layer, whereas layer III presented many GFAP positive cell bodies organized as a dense ribbon (Figure 1c). Their typical astrocyte morphology was associated with processes of irregular caliber with no specific orientation. In this area, control cases had a higher number of GFAP positive cells than AD cases $(189 \pm 3$ cells $/ \mathrm{mm}^{2}$ and $83 \pm 22$ cells $/ \mathrm{mm}^{2}$, respectively; $\mathrm{P}<0.0001$ ) (Table 1 and Figure $2 \mathrm{f}$ ). No correlation was found between GFAP-positive cell density and AD progression $(\mathrm{P}=0.123)$, but in all $\mathrm{AD}$ samples a dense population of well-delineated astrocytes appeared deep in parenchyma of caudate nucleus (data not shown). 
Nestin immunohistochemistry identified a dense population of polymorphic small cells, forming groups or short chains, mainly localized in layer III and parenchyma, and whose multiple short processes were oriented radially to the hypocellular layer (Figure 1d). Other nestin positive cells had larger cell bodies and unipolar or multipolar organization with few or no visible processes. Small nestin positive cells were occasionally detected in layer II and the transitional zone (Layer IV), especially in AD cases. When control and AD cases were compared no significant increase in the density of nestin positive cells was found $\left(159 \pm 1.7\right.$ cells $/ \mathrm{mm}^{2}$ and $218 \pm 55$ cells $/ \mathrm{mm}^{2}$, respectively; $\mathrm{P}=0.139$ ) (Table 1 and Figure 2e), but a positive correlation with $\mathrm{AD}$ progression was found $\left(\mathrm{r}^{2}=0.593, \mathrm{P}=0.038\right.$; figure 3$)$ indicating an increase of progenitors during the course of the disease. Also, a significant increase of the Nestin/GFAP ratio between control and AD cases was observed $(0.84 \pm 0.007$ and 2.59 \pm 0.29 respectively, $\mathrm{P}=0.0013)$. However no relationship between Nestin and GFAPpositive cell number alteration with $\mathrm{AD}$ progression were observed (fig 3a-b).

In all samples, a few activated microglial cells were detected in layers III and IV, and also in the hypocellular layer (layer II) in controls and AD cases (figure 1e). No significant increase of HLA-DR positive cells was found in the SVZ when control and AD cases were compared $\left(80.3 \pm 5.1\right.$ cells $/ \mathrm{mm}^{2}$ and $78 \pm 1.0$ cells $/ \mathrm{mm}^{2}$, respectively; $\mathrm{P}=0.958$, Figure $2 \mathrm{~h}$ ) and no correlation was found between microglial density and disease progression $(\mathrm{P}=0.937)$ nor between Nestin-positive cells and microglia in the SVZ (figure 3g-h). In contrast, stronger microglial activation with profusion of ramifications was observed in the brain parenchyma of AD cases (raw data not shown). In all control and $\mathrm{AD}$ cases, $\mathrm{A} \beta$ protein deposition was mostly absent in layers I-IV of the SVZ (Figure 1f) with the exception of the stage VI AD cases, that present a few small amyloid deposits in layer III. Extracellular amyloid fibrils were also observed in 
layer III, in medium-sized and small wall arteries and arterioles of all AD samples (data not shown).

\section{MAO-B localization in the SVZ}

Quantitative MAO-B enzyme autoradiography (Saura et al., 1997) clearly showed that SVZ constitutes a human brain area rich in MAO-B (Figure 2a) but, due to the technique, no information on the cellular types expressing this enzyme was provided. In this paper, MAO-B cellular localization was characterized in the SVZ of all samples using three different methods. When histochemical procedures were performed, a typical MAO-B positive cell distribution in the cerebral area was found (Figure 2b). Positive MAO-B cells were mainly localized in Layer III of the SVZ, striatal brain parenchyma and subcortical white matter. In the SVZ, most MAO-B positive cells presented a stellate morphology, but positive processes were occasionally observed in layer II, parallel to the lateral wall of lateral ventricle (inset in figure 2b). Small proliferation of MAO-B positive cells was observed in layer II of samples of AD stage VI (data not shown). MAO-B positive cells were also detected by immunohistochemistry with similar cell morphology and distribution as described above for MAO-B histochemistry. MAO-B specific immunostaining was found in cells showing the morphology of astrocytes in the SVZ and in the cerebral parenchyma (Figure 2c). Parallel positive MAO-B processes were not detected, but instead positive fine punctuated cellular ramifications with no consistent orientation were observed. When MAO-B immunopositive cells were quantified, cell density was significantly decreased in the SVZ of all AD cases when compared with controls (mean density 118 \pm 1.7 cells $/ \mathrm{mm}^{2}$ in controls and $96 \pm 7.1$ in $\mathrm{AD}$ samples cells $\left./ \mathrm{mm}^{2}, \mathrm{P}=0.0178\right)($ Table 1 , Figure 2e). This decrease did not correlate with $\mathrm{AD}$ stages progression $(\mathrm{P}=0.131)$. Western blot analysis of SVZ and caudate nucleus parenchyma evidenced a similar 
specific intensely band corresponding to MAO-B molecular weight (Figure 2d). The difficult preservation of SVZ integrity, caused by the post-mortem time, and tissue dissection render unreliable western blot quantification.

When the GFAP/MAO-B ratio was studied a significant $43.7 \%$ decrease was found in $\mathrm{AD}$ cases when compared with controls $(1.6 \pm 0.003$ and $0.9 \pm 0.08$ respectively, $\mathrm{P}=0.014)$ (Figure 3e-f), but no correlation with $\mathrm{AD}$ progression was detected $(\mathrm{P}=0.159)$ nor between GFAP and MAO-B cell counts. When the nestin/MAO-B ratio was analyzed, a significant $68 \%$ increase was found in $\mathrm{AD}$ cases when compared with controls $(1.35 \pm 0.01$ for controls and $2.27 \pm 0.23$ for pathology, $\mathrm{P}=0.013)$ (Figure 3cd). The correlation between this nestin/MAO-B ratio and the progression of the AD stages reached significance $(\mathrm{P}=0.025)$. Finally, the nestin/HLA-DR ratio revealed no difference and no correlation with $\mathrm{AD}$ progression ( $\mathrm{P}=0.369$ and $\mathrm{P}=0.066$, respectively).

\section{Co-localization of SVZ markers}

Nestin-GFAP double confocal immunohistochemistry revealed the presence of abundant astrocyte-like cells in layer III and also a significant presence in layer IV, with cell processes or somata exhibiting both nestin- and GFAP-immunoreactivities. Doubleimmunoreactive cell bodies had oval or fusiform shapes, and exhibited prominent, long slender processes that developed parallel to the wall of the lateral ventricle of anterior horn. In the body of ventricle, these processes appeared with no special organization. Nearly all nestin-positive cells expressed GFAP, and a major proportion of GFAP positive cells were also positive for nestin (Figure 4a-c). The few cells found positive for nestin with no astrocytic features were more abundant in the parenchyma, especially in stage VI of AD samples. 
In all control samples, double nestin-MAO-B immunohistochemistry revealed the presence of large cells with stellate morphology in layer III and in the hypocellular layer of the SVZ nearby blood vessels (Figure 4d-f). Some 35\% of nestin-positive cells were also positive for MAO-B and a similar percent of MAO-B positive cells also expressed nestin. Fewer nestin/MAO-B-positive cells with a smaller round-shape were observed in AD samples. In all double-immunostained cells, labeling of nestin was mostly located in soma and MAO-B in soma and processes (Figure 4g-i), except in AD stage VI in which MAO-B was more localized in processes. Few double-immunostained roundshape cells and unipolar and bipolar cells were also detected in the transitional zone and striatal parenchyma. Finally, nestin-immunoreactivity and HLA-DR-immunolabeling showed no co-localization. In the SVZ, HLA-DR positive cells were observed, mainly in layer III and IV. No spatial relationship between nestin-positive and HLA-DRpositive cells was observed, except in AD samples where some HLA-DR positive cells surrounded nestin-positive cells (data not shown).

\section{DISCUSSION}

The present study gives evidence for the first time that MAO-B is expressed in SVZ progenitor cells of the human brain between 44 and 90 years. Morphological examination of the anterior horn and body of human lateral ventricle confirmed that adult human SVZ is organized into four specific layers (I-IV) with the SVZ astrocytes separated from the ependyma (I) by a hypocellular region (II) devoid of cells bodies. These astrocytes mainly localized in layer III, formed a cell ribbon before the transitional zone (IV) to parenchyma (Quinones-Hinojosa et al., 2006; Sanai et al., 2004). Our data indicate an increase in progenitors in the SVZ during the course of AD. Neurogenesis in the SVZ is increased in acute neurological disorders, such as ischemia 
and epilepsy (Blumcke et al., 2001; Felling and Levison, 2003; Kokaia and Lindvall, 2003) or in neurodegenerative disorders such as AD, Creutzfeldt-Jakob disease or brain tumors (Jackson and Alvarez-Buylla, 2008; Jin et al., 2004; Mizuno et al., 2006; Quinones-Hinojosa and Chaichana, 2007; Waldau and Shetty, 2008; Ziabreva et al., 2006). In this study we found that expression of markers of radial cell differentiation is independent of neurodegeneration, in spite of the small deposition of $\mathrm{A} \beta$ protein and microglial reaction present in layers I-IV of the germinal zone.

According to previous immunohistochemical and enzyme-histochemical studies, MAO-B is localized in human brain astrocytes as well as in serotoninergic and histaminergic neurons of the raphe nuclei and posterior hypothalamus (Konradi et al., 1988; Konradi et al., 1989). In this study, post-mortem delay ranged from $3 \mathrm{~h}$ to $19 \mathrm{~h}$, and the sample time of storage prior to experiment ranged from 1 to 6 months. In these conditions, MAO-B remains a stable protein, and when present, its variation has been related with a cellular process. We and other authors have previously described a widespread increase of MAO-B expression in human brain aging, as a consequence of a general astroglial hypertrophy and/or hyperplasia (Nakamura et al., 1990; Saura et al., 1997; Saura et al., 1994). This astroglial up-regulation of MAO-B activity is closely related with AD senile plaques in cortical layers (Nakamura et al., 1990; Saura et al., 1997; Saura et al., 1994).

However, the high expression of MAO-B in the SVZ in similar brain aging conditions, and its high level in ventricle ependyma, shown previously by quantitative MAO-B enzyme autoradiography (Saura et al., 1997) argue for a new cellular process, different from astrogliosis. Co-localization of MAO-B and nestin indicates the expression of a new marker of human adult SVZ, a zone that remains mitotically active in mammals throughout adult life (Alvarez-Buylla and Garcia-Verdugo, 2002; Merkle et al., 2004). 
The nestin/GFAP positive cells were abundant in SVZ layer III and organized as a continuous ribbon whereas nestin/MAO-B positive cells localized in layer III were less abundant and with no clear organization. Some nestin/MAO-B positive round-shaped cells and unipolar and bipolar cells were also detected in the transitional zone or layer IV of SVZ and brain parenchyma. In this portion of the germinal zone, MAO-B cellular localization appeared increased in the filaments in all the pathological cases, and more especially in the AD cases. The positive correlation between nestin/MAO B ratio and progression of the disease, and the increased nestin/GFAP ratio found in AD, could reflect the increased progenitor activity previously described in these patients (Ziabreva et al., 2006). Finally, the nestin positive cells lacking GFAP, that we found in SVZ and parenchyma in $\mathrm{AD}$ stage VI samples, could represent fully committed migrating neuroblasts (Kronenberg et al., 2003).

GFAP and nestin have been the predominant markers used to describe stem and progenitor cells in mammalian CNS (Bernier et al., 2000; Doetsch et al., 1997; Doetsch et al., 1999; Ihrie and Alvarez-Buylla, 2008). In response to brain injury or degeneration, mature reactive GFAP positive astrocytes can express nestin and revert to embryonic phenotype of neuroepithelial stem cells (Bernier et al., 2000; Lin et al., 1995). In our study, nearly all nestin-positive cells also express GFAP and but only $35 \%$ express MAO-B. The nestin/GFAP positive cells devoid of MAO-B may represent a distinct subpopulation that proliferates during an earlier phase of maturation. Dopamine-induced proliferation of precursor cells in the SVZ has been recently reported (O'Keeffe et al., 2009). As dopamine tissue content depends on MAO-B activity (Youdim et al., 2006), the increased MAO-B expression herein evidenced could be related to modulation of that progenitor cell proliferation. If true, MAO-B expression would take place in a further step of nestin/GFAP-positive cell maduration, to limit 
proliferation and facilitate the subsequent differentiation of progenitor cells. In the early AD stages, the increased nestin positive cells paralleled by a marked reduction of GFAP immunoreactivity evidences proliferation of progenitor cells and differentiation to neuroblasts (Kronenberg et al., 2003) or to newborn cells degenerated in the niche of germinal zone. In these conditions, the discrete MAO-B reduction, different from the severe GFAP decrease would reflect the capacity of progenitor cells to adapt to the neurodegenerative process at the SVZ level by increasing their differentiation rate. However, further investigation is required to decipher MAO-B participation in progenitor cells maturation and differentiation in control and neuropathological conditions. Anyhow, MAO-B labeling brings a new reliable tool for SVZ human stem cell study in control and pathological conditions. Finally, because of the marked differences between adult human and other vertebrates SVZ, our work highlights the importance of studying these cells in the human brain, especially when related to CNS diseases.

\section{REFERENCES}

Alvarez-Buylla A, Garcia-Verdugo JM. 2002. Neurogenesis in adult subventricular zone. J Neurosci 22: 629-634.

Arai R, Kimura H, Maeda T. 1986. Topographic atlas of monoamine oxidase containing neurons in the rat brain studied by an improved histochemical method. Neuroscience 19: $905-925$.

Bernier PJ, Bedard A, Vinet J, Levesque M, Parent A. 2002. Newly generated neurons in the amygdala and adjoining cortex of adult primates. Proc Natl Acad Sci USA 99: 11464-11469. 
Bernier PJ, Vinet J, Cossette M, Parent A. 2000. Characterization of the subventricular zone of the adult human brain: evidence for the involvement of Bcl-2. Neurosci Res 37: 67-78.

Blumcke I, Schewe JC, Normann S, Brustle O, Schramm J, Elger CE, Wiestler OD. 2001. Increase of nestin-immunoreactive neural precursor cells in the dentate gyrus of pediatric patients with early-onset temporal lobe epilepsy. Hippocampus 11: 311321.

Braak H, Braak E. 1991. Neuropathological stageing of Alzheimer-related changes. Acta Neuropathol 82: 235-259.

Christie BR, Cameron HA. 2006. Neurogenesis in the adult hippocampus. Hippocampus 16: 199-207.

Doetsch F, Caille I, Lim DA, Garcia-Verdugo JM, Alvarez-Buylla A. 1999. Subventricular zone astrocytes are neural stem cells in the adult mammalian brain. Cell 97: 703-716.

Doetsch F, Garcia-Verdugo JM, Alvarez-Buylla A. 1997. Cellular composition and three-dimensional organization of the subventricular germinal zone in the adult mammalian brain. J Neurosci 17: 5046-5061.

Emilsson L, Saetre P, Balciuniene J, Castensson A, Cairns N, Jazin EE. 2002. Increased monoamine oxidase messenger RNA expression levels in frontal cortex of Alzheimer's disease patients. Neurosci Lett 326: 56-60.

Felling RJ, Levison SW. 2003. Enhanced neurogenesis following stroke. J Neurosci Res 73: $277-283$. 
Garcia AD, Doan NB, Imura T, Bush TG, Sofroniew MV. 2004. GFAP-expressing progenitors are the principal source of constitutive neurogenesis in adult mouse forebrain. Nat Neurosci 7: 1233-1241.

Gross CG. 2000. Neurogenesis in the adult brain: death of a dogma. Nat Rev Neurosci 1: 67-73.

Ihrie RA, Alvarez-Buylla A. 2008. Cells in the astroglial lineage are neural stem cells. Cell Tissue Res 331: 179-191.

Imura T, Kornblum HI, Sofroniew MV. 2003. The predominant neural stem cell isolated from postnatal and adult forebrain but not early embryonic forebrain expresses GFAP. J Neurosci 23: 2824-2832.

Jackson EL, Alvarez-Buylla A. 2008. Characterization of adult neural stem cells and their relation to brain tumors. Cells Tissues Organs 188: 212-224.

Jin K, Peel AL, Mao XO, Xie L, Cottrell BA, Henshall DC, Greenberg DA. 2004. Increased hippocampal neurogenesis in Alzheimer's disease. Proc Natl Acad Sci USA 101: 343-347.

Kennedy BP, Ziegler MG, Alford M, Hansen LA, Thal LJ, Masliah E. 2003. Early and persistent alterations in prefrontal cortex MAO A and B in Alzheimer's disease. J Neural Transm 110: 789-801.

Kokaia Z, Lindvall O. 2003. Neurogenesis after ischaemic brain insults. Curr Opin Neurobiol 13: 127-132.

Konradi C, Kornhuber J, Froelich L, Fritze J, Heinsen H, Beckmann H, Schulz E, Riederer P. 1989. Demonstration of monoamine oxidase-A and -B in the human brainstem by a histochemical technique. Neuroscience 33: 383-400. 
Konradi C, Svoma E, Jellinger K, Riederer P, Denney R, Thibault J. 1988. Topographic immunocytochemical mapping of monoamine oxidase-A, monoamine oxidase-B and tyrosine hydroxylase in human post-mortem brain. Neuroscience 26: 791-802.

Kornack DR, Rakic P. 2001. The generation, migration, and differentiation of olfactory neurons in the adult primate brain. Proc Natl Acad Sci USA 98: 4752-4757.

Kronenberg G, Reuter K, Steiner B, Brandt MD, Jessberger S, Yamaguchi M, Kempermann G. 2003. Subpopulations of proliferating cells of the adult hippocampus respond differently to physiologic neurogenic stimuli. J Comp Neurol 467: 455-463.

Kumar MJ, Andersen JK. 2004. Perspectives on MAO-B in aging and neurological disease: where do we go from here? Mol Neurobiol 30: 77-89.

Levison S, Goldman J. 1993. Both oligodendrocytes and astrocytes develop from progenitors in the subventricular zone of postnatal rat forebrain. Neuron 10: 201-212.

Lie DC, Song H, Colamarino SA, Ming GL, Gage FH. 2004. Neurogenesis in the adult brain: new strategies for central nervous system diseases. Annu Rev Pharmacol Toxicol 44: 399-421.

Lin RC, Matesic DF, Marvin M, McKay RD, Brustle O. 1995. Re-expression of the intermediate filament nestin in reactive astrocytes. Neurobiol Dis 2: 79-85.

Lledo PM, Merkle FT, Alvarez-Buylla A. 2008. Origin and function of olfactory bulb interneuron diversity. Trends Neurosci 31: 392-400.

Merkle FT, Tramontin AD, Garcia-Verdugo JM, Alvarez-Buylla A. 2004. Radial glia give rise to adult neural stem cells in the subventricular zone. Proc Natl Acad Sci USA 101: 17528-17532. 
Mizuno Y, Ohama E, Hirato J, Nakazato Y, Takahashi H, Takatama M, Takeuchi T, Okamoto K. 2006. Nestin immunoreactivity of Purkinje cells in Creutzfeldt-Jakob disease. J Neurol Sci 246: 131-137.

Nakamura S, Kawamata T, Akiguchi I, Kameyama M, Nakamura N, Kimura T. 1990. Expression of monoamine oxidase B activity in astrocytes of senile plaques. Acta Neuropathol 80: 319-325.

Newell KL, Hyman BT, Growdon JH, Hedley-Whyte ET. 1999. Application of the National Institute on Aging (NIA)-Reagan Institute criteria for the neuropathological diagnosis of Alzheimer disease. J Neuropathol Exp Neurol 58: 1147-1155.

O'Keeffe GC, Tyers P, Aarsland D, Dalley JW, Barker RA, Caldwell MA. 2009. Dopamine-induced proliferation of adult neural precursor cells in the mammalian subventricular zone is mediated through EGF. Proc Natl Acad Sci USA 106: 87548759

Quinones-Hinojosa A, Chaichana K. 2007. The human subventricular zone: A source of new cells and a potential source of brain tumors. Exp Neurol 205: 313-324.

Quinones-Hinojosa A, Sanai N, Soriano-Navarro M, Gonzalez-Perez O, Mirzadeh Z, Gil-Perotin S, Romero-Rodriguez R, Berger MS, Garcia-Verdugo JM, AlvarezBuylla A. 2006. Cellular composition and cytoarchitecture of the adult human subventricular zone: a niche of neural stem cells. J Comp Neurol 494: 415-434.

Rodríguez MJ, Saura J, Finch CC, Mahy N, Billett EE. 2000. Localization of monoamine oxidase $\mathrm{A}$ and $\mathrm{B}$ in human pancreas, thyroid, and adrenal glands. J Histochem Cytochem 48: 147-151.

Sanai N, Tramontin AD, Quinones-Hinojosa A, Barbaro NM, Gupta N, Kunwar S, Lawton MT, McDermott MW, Parsa AT, Manuel-Garcia VJ, Berger MS, Alvarez- 
Buylla A. 2004. Unique astrocyte ribbon in adult human brain contains neural stem cells but lacks chain migration. Nature 427: 740-744.

Saura J, Andrés N, Andrade C, Ojuel J, Eriksson K, Mahy N. 1997. Biphasic and region-specific MAO-B response to aging in normal human brain. Neurobiol Aging 18: $497-507$.

Saura J, Luque JM, Cesura AM, Da Prada M, Chan Palay V, Huber G, Löffler J, Richards JG. 1994. Increased monoamine oxidase B activity in plaque-associated astrocytes of Alzheimer brains revealed by quantitative enzyme radioautography. Neuroscience 62: 15-30.

Schnell SA, Staines WA, Wessendorf MW. 1999. Reduction of lipofuscin-like autofluorescence in fluorescently labeled tissue. J Histochem Cytochem 47: 719-730.

Taupin P. 2006. Neurogenesis in the adult central nervous system. C R Biol 329: 465475.

Waldau B, Shetty AK. 2008. Behavior of neural stem cells in the Alzheimer brain. Cell Mol Life Sci.

Wei LC, Shi M, Chen LW, Cao R, Zhang P, Chan YS. 2002. Nestin-containing cells express glial fibrillary acidic protein in the proliferative regions of central nervous system of postnatal developing and adult mice. Brain Res Dev Brain Res 139: 9-17.

Yeomanson KB, Billett EE. 1992. An enzyme immunoassay for the measurement of human monoamine oxidase B protein. Biochim Biophys Acta 1116: 261-268.

Youdim MB, Edmondson D, Typton KF. 2006. The therapeutic potencial of monoamine oxidase inhibitors. Nat Rev Neurosci 7: 295-309. 
Ziabreva I, Perry E, Perry R, Minger SL, Ekonomou A, Przyborski S, Ballard C. 2006. Altered neurogenesis in Alzheimer's disease. J Psychosom Res 61: 311-316.

\section{FIGURE LEGENDS}

Figure 1: Histological characterization of human SVZ in AD cases. (a, b) AD stage VI; Nissl staining showed the anterior horn region and body of ventricle region with a characteristic layer organization. The ependymal cells formed layer I, whereas layer II, a hypocellular region formed a gap with layer III that was organized as a dense ribbon of cell bodies. Finally layer IV represented a transitional zone to the striatal brain parenchyma. c) AD stage II; GFAP immunostaining of showed layer II as the most GFAP-immunoreactive area, with the GFAP immunopositive cell bodies localized in layer III. d) AD stage VI; nestin immunopositive cells were localized mainly in layer III (arrowheads) sometimes formed small chains, with short processes oriented radially to the hypocellular layer. e) AD stage II; scarcely activated microglial cells detected by HLA-DR immunohistochemistry were found mainly in the layer II (arrowhead). Microglial positive cells were also detected in the transitional zone (asterisk) (Layer IV) and brain parenchyma. f) AD stage II; cerebral A $\beta$ protein deposition was practically absent in the human SVZ, except in AD stage VI cases where small amyloid deposits were detected in layer III. In AD cases amyloid-beta deposition was abundantly present in the brain parenchyma. LV: Lateral ventricle. Scale bar: a-e $50 \mu \mathrm{m}$; f, $200 \mu \mathrm{m}$

Figure 2: Evidences of MAO-B localization in the SVZ of AD cases. (a) Quantitative $\left[{ }^{3} \mathrm{H}\right]$ lazabemide in vitro autoradiography of human basal ganglia samples evidenced the highest brain MAO-B labeling in the SVZ (arrow) (Results extracted from Saura et al. 1997). (b) AD stage V; histochemistry showed MAO-B activity labeling in the SVZ, 
especially in astrocytes of layer III (arrows and inset). (c) AD stage V; MAO-B immunohistochemistry counterstained with haematoxylin (cellular nuclei stained in blue) in the SVZ and parenchyma evidenced MAO-B staining (brown) in the cells with astrocyte morphology. (d) MAO-B western blot analysis of the SVZ and striatal parenchyma (parem) brain samples. (e-h) Scater plot and histograms of cell counts from the different markers included in the study, in control subjects $(n=3)$ and AD subjects $(n=7)$. Note the different AD-induced change between Nestin positive cell count and GFAP or MAO-B positive cell counts. LV: Lateral ventricle. AD, Alzheimer's disease. Scale bars: a, $3 \mathrm{~mm}, \mathrm{~b}, 50 \mu \mathrm{m}$; c and inset in b, $15 \mu \mathrm{m} * \mathrm{p}<0.05 ; * * \mathrm{p}<0.01 ; * * *$ p $<0.001$ vs. control (LSD post-hoc).

Figure 3: Estimation of the AD changes in the relationship between Nestin, GFAP, MAO-B, and HLA-DR positive cell counts in the SVZ. The ratio estimation and dispersion plot of Nestin/GFAP (a,b), Nestin/MAO-B (c,d), GFAP/MAO-B (e,f), and Nestin/HLA-DR (g,h) immunopositive cells evidenced an AD-associated decrease of GFAP-immunopositive cells with respect to both Nestin and MAO-B positive cells. Please note an AD-stage associated increase of nestin positive cells ( $\mathrm{r} 2=0.593, \mathrm{p}=$ 0.038) in dispersion plots b, d and h. AD, Alzheimer's disease; Stage II and Stage V-VI refers to Stages of AD cases. * $\mathrm{p}<0.05$; vs. control (LSD post-hoc).

Figure 4: Co-localization of SVZ markers of AD cases. (a-c) AD stage V; the double confocal immunohistochemistry of body of ventricle showing GFAP in green and nestin in red, revealed the presence of oval or fusiform astrocyte-like cells mostly in layer III (merge), with positive large and extensive with no special organization. (d-f) AD stage VI; the double confocal nestin (red) / MAO-B (green) immunohistochemistry revealed 
the presence of round-shape cells and unipolar and bipolar cells in layer III and the transitional zone and striatal brain parenchyma (merge) especially in AD samples. (g-i) In control samples the presence of nestin (red) / MAO-B (green) positive large cells with stellate morphology were detected in layer III and in the hypocellular layer nearby blood vessels (merge). Scale bar: a-f, $40 \mu \mathrm{m}$; g-i, $16 \mu \mathrm{m}$. 


\section{ALZHEIMER'S DISEASE MODIFIES PROGENITOR CELL EXPRESSION OF MONOAMINE OXIDASE B IN THE SUBVENTRICULAR ZONE}

Marco Pugliese ${ }^{1}$, Manuel J. Rodríguez ${ }^{1}$, Javier Gimeno-Bayon ${ }^{1}$, Lluís Pujadas ${ }^{1}$, Ellen E. Billett ${ }^{2}$, Cheryl Wells ${ }^{2}$ and Nicole Mahy ${ }^{1}$

(1) Unitat de Bioquímica i Biologia Molecular, Facultat de Medicina, Institut d'Investigacions Biomèdiques August Pi i Sunyer (IDIBAPS), Universitat de Barcelona and Centro de Investigación Biomédica en Red sobre Enfermedades Neurodegenerativas (CIBERNED), Barcelona, Spain

(2) School of Science and Technology, Nottingham Trent University, Clifton Lane, Nottingham, NG11 8NS, UK

* Corresponding author: Dr. Nicole Mahy

Unitat de Bioquímica

Fac. Medicina, UB.

c/ Casanova, 143

08036 Barcelona, SPAIN

TEL: +34934024525

FAX: +349340358 82

E-mail: nmahy@ub.edu

Running title: AD modifies MAO-B expression in the SVZ

\section{GRANT INFORMATION}

Grant SAF2008-01902 by Ministerio de Ciencia e Innovación (Spain)

Grant 2009SGR1380 by Generalitat de Catalunya (Spain) 


\begin{abstract}
In the adult brain, progenitor cells remaining in the subventricular zone (SVZ) are frequently identified as glial fibrillary acidic protein (GFAP)- positive cells that retain attributes reminiscent of radial glia. Because the very high expression of monoamine oxidase $\mathrm{B}$ (MAO-B) in the subventricular area has been related to epithelial and astroglial expression, we aimed to ascertain whether it was also expressed by progenitor cells of human control and Alzheimer's disease (AD) patients. In the SVZ epithelial cells and astrocyte-like cells presented rich MAO-B activity and immunolabeling. Nestin-positive cells were found in the same area showing a radial-glia-like morphology. When co-immunostaining and confocal microscopy were performed, most nestin-positive cells showed MAO-B activity and labeling. The increased progenitor activity in SVZ proposed in AD patients was confirmed by the positive correlation between the SVZ nestin/MAO-B ratio and the progression of the disease. Nestin/GFAP positive cells, devoid of MAO-B can represent a distinct subpopulation of an earlier phase of maturation. This would indicate that MAO-B expression takes place in a further step of nestin/GFAP positive cells differentiation. In the early AD stages, the discrete MAO-B reduction, different from the severe GFAP decrease would reflect the capacity of this population of MAO-B positive progenitor cells to adapt to the neurodegenerative process.
\end{abstract}

Keywords: Astroglia; MAO-B; Nestin; Neural Stem cells; neurogenesis. 


\section{INTRODUCTION}

Neural progenitor/stem cells characterized in adult human brain possess the characteristics of self-renewal, proliferation and differentiation along all major neural lineages. (Gross, 2000; Lie et al., 2004; Taupin, 2006). Their development progress in a permissive microenvironment and proceeds in several stages characterized by their morphology, and by gene expression of specific markers such as glial fibrillary acidic protein (GFAP) and the intermediate filament protein nestin (Garcia et al., 2004; Imura et al., 2003; Wei et al., 2002).

In adult mammalian brain, germinal regions are the subventricular zone (SVZ) of the lateral ventricle and the subgranular zone within the dentate gyrus of the hippocampus and present abundant multipotent neural stem cells showing structural and biological markers of astroglia (Alvarez-Buylla and Garcia-Verdugo, 2002; Christie and Cameron, 2006; Ihrie and Alvarez-Buylla, 2008). In rodent, SVZ is the source of new specific type of neurons destined to the olfactory bulb (Kornack and Rakic, 2001; Lledo et al., 2008) and of oligondendrocytes during development (Levison and Goldman, 1993). Human SVZ also harbors abundant multipotent progenitor cells exhibiting markers of adult neurogenesis (Bernier et al., 2000; Bernier et al., 2002) that correspond to astrocytes (Doetsch et al., 1999; Sanai et al., 2004). In contrast to rodent, human SVZ astrocytes are not found adjacent to the ependymal layer, but forming a ribbon of cells lining the lateral ventricle, with no evidence of migrating neuroblasts (QuinonesHinojosa et al., 2006; Sanai et al., 2004).

Basic questions regarding progenitor cell biology and mechanisms of differentiation remain open. As very few markers allow differentiating a multipotent radial-glia-like stem cell from a progenitor one, it remains difficult to identify with enough criteria their 
future neuronal development. A better knowledge of the specific expression of each cell type is then needed to allow a clear discrimination.

With regard to astroglial markers, expression of GFAP has been found in human adult SVZ progenitor cells whereas the $\mathrm{S}-100 \beta$ presence is restricted to mature cells. However information concerning other well-identified astroglial markers remains elusive. Characterization of astroglial response based on monoamine oxidase B (MAOB; EC 1.4.3.4) expression has evidenced very high SVZ labeling in adult brain that could not be limited to epithelial and astroglial cells (Saura et al., 1997). With human aging, brain MAO-B activity increases progressively, beginning around the age of 5060 years (Kumar and Andersen, 2004; Saura et al., 1997), associated with increased astrogliosis. In Alzheimer's disease (AD) patients a further increased SVZ MAO-B expression has been observed (Emilsson et al., 2002; Kennedy et al., 2003; Saura et al., 1994), together with an increased SVZ progenitor activity associated with key pathological and neurochemical substrates (Ziabreva et al., 2006). In this study we investigated whether increased MAO-B expression in the SVZ of $\mathrm{AD}$ is related to endogenous proliferation and differentiation of progenitor cells. To help define the process of progenitor cell differentiation and begin approaching the underlying mechanisms present in neurodegenerative diseases, we investigated the specific expression of MAO-B in the SVZ and evaluated its relationship with specific progenitor cell and astrocyte markers in $\mathrm{AD}$ patients compared to age-matched controls.

\section{MATERIALS AND METHODS}

\section{Human post-mortem brain tissue}

Human post-mortem tissue samples of SVZ of the lateral ventricle walls corresponded to the anterior horn and body of ventricle regions were selected for this study. They 
included the head and the body of caudate nucleus (Quinones-Hinojosa et al., 2006) and were obtained from our local Neurological Tissue Bank (Serveis Cientifico-Tècnics, Universitat de Barcelona, Barcelona, Spain) according to the European ethics guidelines and approved by the appropriated Research Ethics Committee. Brains were obtained at autopsy from individuals that suffered a clinical history of $\mathrm{AD}(\mathrm{n}=7$, stages II, V, VI, aged 79-91 years) and from non-demented controls ( $n=3$, aged 44-74 years) (see Table 1 for a summary of case histories). Neuropathological confirmation of the clinical diagnosis was undertaken at the Neurological Tissue Bank according to Braak and Newell criteria (Braak and Braak, 1991; Newell et al., 1999). The investigation was carried out on tissues that were either fresh-frozen and stored at $-80^{\circ} \mathrm{C}$ or paraffinembedded; 35 serial sections where obtained from each one of them. Sections thickness was $12 \mu \mathrm{m}$ for fresh-frozen tissue and $8 \mu \mathrm{m}$ for paraffin embedded tissue. All sections were mounted in slices (one section each) and used for histological and immunohistochemical procedures.

\section{Materials}

Clorgyline hydrochloride was purchased from Research Biochemicals Inc, (USA), the Immobilon-P membranes from Millipore (Bedford, MA) and the Lumi-Light enhanced chemiluminescence ECL from Roche Diagnostics (Mannheim, Germany). The rabbit anti-nestin polyclonal antibody was purchased from CHEMICON International (Temecula CA, USA), the mouse monoclonal anti-MHC II (HLA-DR) Ab-1 (Clone LN3) from Neomarkers (Fremont CA, USA), and the mouse monoclonal anti-A $\beta_{8-17}$ was from DakoCytomation (Glostrup, Denmark). The mouse monoclonal anti-GFAP, the secondary antibodies and immunohistochemical reagents were from Sigma (St. Louis MO, USA, except for Alexa488 conjugated anti-rabbit IgG antibody and 
Alexa546 conjugated anti-mouse IgG antibody which were from Molecular Probes (Madrid, Spain).

\section{Western blot analysis of MAO-B}

Frozen $100 \mu \mathrm{g}$ samples from dissected SVZ or brain parenchyma were manually homogenized in 5 volumes of ice-cold Tris-HCl $50 \mathrm{mM}, \mathrm{pH} 7.7$ and centrifuged at $15000 \mathrm{rpm}$ for $10 \mathrm{~min}, 4^{\circ} \mathrm{C}$. The pellet was resuspended in ice cooled Tris- $\mathrm{HCl}$ and centrifuged twice more. The final pellet was resuspended in Tris- $\mathrm{HCl}$ incubation buffer. Protein content was determined by the method of Bradford using bovine serum albumin as standard. Western blot analysis was performed as previously described (Yeomanson and Billett, 1992) using the mouse monoclonal anti-MAO-B antibody 3F12/G10/2E3. Immobilon-P membranes were used for electroblotting. Blots were probed with antiMAO-B antibody (1:500, v/v) and binding was detected using an HRP-conjugated antimouse IgG antibody. Incubation with no primary antibody was used to control the specificity of results. The immunocomplexes were developed using Lumi-Light ECL.

\section{Histology and immunohistochemistry}

Nissl staining was performed according to standard procedure with cresyl violet on four sections of every paraffin-embedded tissue. MAO-B histochemistry was performed according to Arai (Arai et al., 1986). Briefly, after washing with $0.01 \mathrm{M}$ phosphate buffer saline (PBS), 5 cryostat sections of every fresh-frozen tissue were incubated in a reaction medium for $48 \mathrm{~h}$ at $4^{\circ} \mathrm{C}$. The medium consisted of $75 \mathrm{mg}$ tyramine hydrochloride, $5 \mathrm{mg}$ 3-3'-diaminobenzidine (DAB), $100 \mathrm{mg}$ horseradish peroxidase, $600 \mathrm{mg}$ nickel ammonium sulphate and $10^{-6} \mathrm{M}$ clorgyline hydrochloride for monoamine oxidase A inhibition. MAO-B activity appeared in the tissue sections as dark-blue precipitates. 
For nestin, GFAP, HLA-DR, and amyloid-beta (A $\beta)$ immunohistochemistry analysis, 12 serial paraffin-embedded SVZ sections of every brain sample were processed with the avidin-biotin peroxidase method. For $\mathrm{A} \beta$ immunohistochemistry, sections were previously incubated with $98 \%$ formic acid for 3 min to enhance antigenicity. A 30-min preincubation in $\mathrm{H}_{2} \mathrm{O}_{2}$-methanol-PBS $(0.3 / 9.7 / 90)$ was performed in all slices to inhibit non-specific staining in blood vessels and neurons. Sections were incubated at room temperature in blocking solution (0.01 M PBS $+3 \%$ normal goat serum, $0.1 \%$ Triton $\mathrm{X}$ 100) for $2 \mathrm{~h}$ and separately incubated overnight at $4^{\circ} \mathrm{C}$ with the primary antibody at the appropriated dilution in blocking solution. After washing and incubation with the appropriated biotinilated secondary antibody, sections were incubated with ExtrAvidin (1:250), and developed in DAB and $\mathrm{H}_{2} \mathrm{O}_{2}$. Some sections were counterstained with Mayer's Haematoxylin.

For MAO-B immunohistochemistry, sections were processed with the avidin-biotin peroxidase method with some modifications (Rodríguez et al., 2000). 3 serial consecutive frozen SVZ sections of every sample were post-fixed with acetone for 3 min. at room temperature. After blocking endogenous peroxidases, sections were incubated for $30 \mathrm{~min}$ at room temperature in blocking solution containing normal pig serum. Overnight incubation was performed at $4^{\circ} \mathrm{C}$ with mouse monoclonal anti-MAOB antibody (3F12/G10/2E3) (Yeomanson and Billett, 1992) diluted 1:50. Then, sections were processed as above described. In all cases, sections stained only with the secondary antibodies were used as negative controls.

According to previous anatomical classification (Quinones-Hinojosa et al., 2006) four layers were observed throughout the SVZ: a monolayer of ependymal cells (Layer I), a hypocellular gap (Layer II), a ribbon of cells (Layer III) composed of astrocytes and a transitional zone (layer IV). These Layers I-IV were observed at the optic microscope 
and 4 areas of interest of $1.0 \mathrm{~mm}^{2}$ each were randomly selected to perform the cell number estimations at a $\mathrm{x} 40$ objective magnification. This counting procedure was performed by duplicate in three different sections of every case sample. Positive cells were counted in layers I-IV from the SVZ to the parenchyma boundary, and quantification was made using the Image Pro Plus v.5.1 image and analysis system (Media Cybernetics Inc., Bethesda, MD, USA).

Double immunofluorescence was performed on 4 fresh-frozen and 4 paraffin-embedded SVZ sections of every sample. Sections were co-incubated overnight at $4^{\circ} \mathrm{C}$ with antinestin antibody and either anti-MAO-B antibody (fresh-frozen tissue), anti-GFAP antibody; or anti-HLA-DR antibody. After washing in PBS, sections were incubated in dark with a cocktail of Alexa488 conjugated anti-rabbit IgG antibody and Alexa546 conjugated anti-mouse IgG antibody. Human brain autofluorescent lipofuscin artifacts were reduced to near background levels by immersion in $70 \%$ ethanol supplemented with $1 \%$ of Sudan black B for 5 min (Schnell et al., 1999). Sections were mounted in Immuno-Fluore Mounting medium (ICN Biomedicals, Barcelona, Spain) and examined with a Leica TCS-SL confocal microscope. Counting of double-stained cells was performed as above explained for single immunohistochemistry procedures. Due to the antibody characteristics and difficult preservation of human sample integrity, no GFAP/MAO-B or GFAP/MAO-B/nestin co-localization could be performed. Because of that, to estimate the relationship between the three cell markers, a correlation analysis was performed and the ratios GFAP/MAO-B, Nestin/GFAP and Nestin/MAO-B were calculated from the cell counts assessed by single immunohistochemistry.

\section{Statistical analysis}

Kurtosis and Skewness moments were calculated to test the normal distribution of data. A one-way analysis of variance followed by the Fisher's least significant difference 
analysis was performed to detect differences. Correlations between cell markers and the progression of $\mathrm{AD}$ were estimated by regression analysis between cell counts and a numerical value assigned to each $\mathrm{AD}$ stage. All values are presented as mean \pm standard error of the mean (SD), and differences were considered to be significant at the $\mathrm{P}<0.05$ level. Data were analyzed with the statistical analysis package StatGraphics 5.0 (STSC Inc., Rockville, MD, USA).

\section{RESULTS}

\section{Characterization of human SVZ}

In all control and $\mathrm{AD}$ cases, the anterior horn region and the body of the ventricle region of human SVZ presented a similar cellular organization (Figure 1a, b) as published elsewere (Quinones-Hinojosa et al., 2006). Ependymal cells were arranged as a one-cell thick epithelium forming Layer I. Layer II, an hypocellular region, formed a gap between Layer I and a dense ribbon of cell bodies (layer III of the SVZ) of different size and morphology. Layer IV was observed as a transitional zone to the striatal brain parenchyma.

GFAP immunohistochemistry revealed an abundance of GFAP positive processes within the hypocellular layer, whereas layer III presented many GFAP positive cell bodies organized as a dense ribbon (Figure 1c). Their typical astrocyte morphology was associated with processes of irregular caliber with no specific orientation. In this area, control cases had a higher number of GFAP positive cells than AD cases $(189 \pm 3$ cells $/ \mathrm{mm}^{2}$ and $83 \pm 22$ cells $/ \mathrm{mm}^{2}$, respectively; $\mathrm{P}<0.0001$ ) (Table 1 and Figure $2 \mathrm{f}$ ). No correlation was found between GFAP-positive cell density and AD progression $(\mathrm{P}=0.123)$, but in all $\mathrm{AD}$ samples a dense population of well-delineated astrocytes appeared deep in parenchyma of caudate nucleus (data not shown). 
Nestin immunohistochemistry identified a dense population of polymorphic small cells, forming groups or short chains, mainly localized in layer III and parenchyma, and whose multiple short processes were oriented radially to the hypocellular layer (Figure 1d). Other nestin positive cells had larger cell bodies and unipolar or multipolar organization with few or no visible processes. Small nestin positive cells were occasionally detected in layer II and the transitional zone (Layer IV), especially in AD cases. When control and AD cases were compared no significant increase in the density of nestin positive cells was found $\left(159 \pm 1.7\right.$ cells $/ \mathrm{mm}^{2}$ and $218 \pm 55$ cells $/ \mathrm{mm}^{2}$, respectively; $\mathrm{P}=0.139$ ) (Table 1 and Figure 2e), but a positive correlation with $\mathrm{AD}$ progression was found $\left(\mathrm{r}^{2}=0.593, \mathrm{P}=0.038\right.$; figure 3$)$ indicating an increase of progenitors during the course of the disease. Also, a significant increase of the Nestin/GFAP ratio between control and AD cases was observed $(0.84 \pm 0.007$ and 2.59 \pm 0.29 respectively, $\mathrm{P}=0.0013)$. However no relationship between Nestin and GFAPpositive cell number alteration with $\mathrm{AD}$ progression were observed (fig 3a-b).

In all samples, a few activated microglial cells were detected in layers III and IV, and also in the hypocellular layer (layer II) in controls and AD cases (figure 1e). No significant increase of HLA-DR positive cells was found in the SVZ when control and AD cases were compared $\left(80.3 \pm 5.1\right.$ cells $/ \mathrm{mm}^{2}$ and $78 \pm 1.0$ cells $/ \mathrm{mm}^{2}$, respectively; $\mathrm{P}=0.958$, Figure $2 \mathrm{~h}$ ) and no correlation was found between microglial density and disease progression $(\mathrm{P}=0.937)$ nor between Nestin-positive cells and microglia in the SVZ (figure 3g-h). In contrast, stronger microglial activation with profusion of ramifications was observed in the brain parenchyma of AD cases (raw data not shown). In all control and $\mathrm{AD}$ cases, $\mathrm{A} \beta$ protein deposition was mostly absent in layers I-IV of the SVZ (Figure 1f) with the exception of the stage VI AD cases, that present a few small amyloid deposits in layer III. Extracellular amyloid fibrils were also observed in 
layer III, in medium-sized and small wall arteries and arterioles of all AD samples (data not shown).

\section{MAO-B localization in the SVZ}

Quantitative MAO-B enzyme autoradiography (Saura et al., 1997) clearly showed that SVZ constitutes a human brain area rich in MAO-B (Figure 2a) but, due to the technique, no information on the cellular types expressing this enzyme was provided. In this paper, MAO-B cellular localization was characterized in the SVZ of all samples using three different methods. When histochemical procedures were performed, a typical MAO-B positive cell distribution in the cerebral area was found (Figure 2b). Positive MAO-B cells were mainly localized in Layer III of the SVZ, striatal brain parenchyma and subcortical white matter. In the SVZ, most MAO-B positive cells presented a stellate morphology, but positive processes were occasionally observed in layer II, parallel to the lateral wall of lateral ventricle (inset in figure 2b). Small proliferation of MAO-B positive cells was observed in layer II of samples of AD stage VI (data not shown). MAO-B positive cells were also detected by immunohistochemistry with similar cell morphology and distribution as described above for MAO-B histochemistry. MAO-B specific immunostaining was found in cells showing the morphology of astrocytes in the SVZ and in the cerebral parenchyma (Figure 2c). Parallel positive MAO-B processes were not detected, but instead positive fine punctuated cellular ramifications with no consistent orientation were observed. When MAO-B immunopositive cells were quantified, cell density was significantly decreased in the SVZ of all AD cases when compared with controls (mean density 118 \pm 1.7 cells $/ \mathrm{mm}^{2}$ in controls and $96 \pm 7.1$ in $\mathrm{AD}$ samples cells $\left./ \mathrm{mm}^{2}, \mathrm{P}=0.0178\right)($ Table 1 , Figure 2e). This decrease did not correlate with $\mathrm{AD}$ stages progression $(\mathrm{P}=0.131)$. Western blot analysis of SVZ and caudate nucleus parenchyma evidenced a similar 
specific intensely band corresponding to MAO-B molecular weight (Figure 2d). The difficult preservation of SVZ integrity, caused by the post-mortem time, and tissue dissection render unreliable western blot quantification.

When the GFAP/MAO-B ratio was studied a significant $43.7 \%$ decrease was found in AD cases when compared with controls $(1.6 \pm 0.003$ and $0.9 \pm 0.08$ respectively, $\mathrm{P}=0.014)$ (Figure 3e-f), but no correlation with $\mathrm{AD}$ progression was detected $(\mathrm{P}=0.159)$ nor between GFAP and MAO-B cell counts. When the nestin/MAO-B ratio was analyzed, a significant $68 \%$ increase was found in $\mathrm{AD}$ cases when compared with controls $(1.35 \pm 0.01$ for controls and $2.27 \pm 0.23$ for pathology, $\mathrm{P}=0.013)$ (Figure $3 \mathrm{c}$ d). The correlation between this nestin/MAO-B ratio and the progression of the AD stages reached significance $(\mathrm{P}=0.025)$. Finally, the nestin/HLA-DR ratio revealed no difference and no correlation with $\mathrm{AD}$ progression ( $\mathrm{P}=0.369$ and $\mathrm{P}=0.066$, respectively).

\section{Co-localization of SVZ markers}

Nestin-GFAP double confocal immunohistochemistry revealed the presence of abundant astrocyte-like cells in layer III and also a significant presence in layer IV, with cell processes or somata exhibiting both nestin- and GFAP-immunoreactivities. Doubleimmunoreactive cell bodies had oval or fusiform shapes, and exhibited prominent, long slender processes that developed parallel to the wall of the lateral ventricle of anterior horn. In the body of ventricle, these processes appeared with no special organization. Nearly all nestin-positive cells expressed GFAP, and a major proportion of GFAP positive cells were also positive for nestin (Figure 4a-c). The few cells found positive for nestin with no astrocytic features were more abundant in the parenchyma, especially in stage VI of AD samples. 
In all control samples, double nestin-MAO-B immunohistochemistry revealed the presence of large cells with stellate morphology in layer III and in the hypocellular layer of the SVZ nearby blood vessels (Figure 4d-f). Some 35\% of nestin-positive cells were also positive for MAO-B and a similar percent of MAO-B positive cells also expressed nestin. Fewer nestin/MAO-B-positive cells with a smaller round-shape were observed in AD samples. In all double-immunostained cells, labeling of nestin was mostly located in soma and MAO-B in soma and processes (Figure 4g-i), except in AD stage VI in which MAO-B was more localized in processes. Few double-immunostained roundshape cells and unipolar and bipolar cells were also detected in the transitional zone and striatal parenchyma. Finally, nestin-immunoreactivity and HLA-DR-immunolabeling showed no co-localization. In the SVZ, HLA-DR positive cells were observed, mainly in layer III and IV. No spatial relationship between nestin-positive and HLA-DRpositive cells was observed, except in AD samples where some HLA-DR positive cells surrounded nestin-positive cells (data not shown).

\section{DISCUSSION}

The present study gives evidence for the first time that MAO-B is expressed in SVZ progenitor cells of the human brain between 44 and 90 years. Morphological examination of the anterior horn and body of human lateral ventricle confirmed that adult human SVZ is organized into four specific layers (I-IV) with the SVZ astrocytes separated from the ependyma (I) by a hypocellular region (II) devoid of cells bodies. These astrocytes mainly localized in layer III, formed a cell ribbon before the transitional zone (IV) to parenchyma (Quinones-Hinojosa et al., 2006; Sanai et al., 2004). Our data indicate an increase in progenitors in the SVZ during the course of AD. Neurogenesis in the SVZ is increased in acute neurological disorders, such as ischemia 
and epilepsy (Blumcke et al., 2001; Felling and Levison, 2003; Kokaia and Lindvall, 2003) or in neurodegenerative disorders such as AD, Creutzfeldt-Jakob disease or brain tumors (Jackson and Alvarez-Buylla, 2008; Jin et al., 2004; Mizuno et al., 2006; Quinones-Hinojosa and Chaichana, 2007; Waldau and Shetty, 2008; Ziabreva et al., 2006). In this study we found that expression of markers of radial cell differentiation is independent of neurodegeneration, in spite of the small deposition of $\mathrm{A} \beta$ protein and microglial reaction present in layers I-IV of the germinal zone.

According to previous immunohistochemical and enzyme-histochemical studies, MAO-B is localized in human brain astrocytes as well as in serotoninergic and histaminergic neurons of the raphe nuclei and posterior hypothalamus (Konradi et al., 1988; Konradi et al., 1989). In this study, post-mortem delay ranged from $3 \mathrm{~h}$ to $19 \mathrm{~h}$, and the sample time of storage prior to experiment ranged from 1 to 6 months. In these conditions, MAO-B remains a stable protein, and when present, its variation has been related with a cellular process. We and other authors have previously described a widespread increase of MAO-B expression in human brain aging, as a consequence of a general astroglial hypertrophy and/or hyperplasia (Nakamura et al., 1990; Saura et al., 1997; Saura et al., 1994). This astroglial up-regulation of MAO-B activity is closely related with AD senile plaques in cortical layers (Nakamura et al., 1990; Saura et al., 1997; Saura et al., 1994).

However, the high expression of MAO-B in the SVZ in similar brain aging conditions, and its high level in ventricle ependyma, shown previously by quantitative MAO-B enzyme autoradiography (Saura et al., 1997) argue for a new cellular process, different from astrogliosis. Co-localization of MAO-B and nestin indicates the expression of a new marker of human adult SVZ, a zone that remains mitotically active in mammals throughout adult life (Alvarez-Buylla and Garcia-Verdugo, 2002; Merkle et al., 2004). 
The nestin/GFAP positive cells were abundant in SVZ layer III and organized as a continuous ribbon whereas nestin/MAO-B positive cells localized in layer III were less abundant and with no clear organization. Some nestin/MAO-B positive round-shaped cells and unipolar and bipolar cells were also detected in the transitional zone or layer IV of SVZ and brain parenchyma. In this portion of the germinal zone, MAO-B cellular localization appeared increased in the filaments in all the pathological cases, and more especially in the AD cases. The positive correlation between nestin/MAO B ratio and progression of the disease, and the increased nestin/GFAP ratio found in $\mathrm{AD}$, could reflect the increased progenitor activity previously described in these patients (Ziabreva et al., 2006). Finally, the nestin positive cells lacking GFAP, that we found in SVZ and parenchyma in $\mathrm{AD}$ stage VI samples, could represent fully committed migrating neuroblasts (Kronenberg et al., 2003).

GFAP and nestin have been the predominant markers used to describe stem and progenitor cells in mammalian CNS (Bernier et al., 2000; Doetsch et al., 1997; Doetsch et al., 1999; Ihrie and Alvarez-Buylla, 2008). In response to brain injury or degeneration, mature reactive GFAP positive astrocytes can express nestin and revert to embryonic phenotype of neuroepithelial stem cells (Bernier et al., 2000; Lin et al., 1995). In our study, nearly all nestin-positive cells also express GFAP and but only $35 \%$ express MAO-B. The nestin/GFAP positive cells devoid of MAO-B may represent a distinct subpopulation that proliferates during an earlier phase of maturation. Dopamine-induced proliferation of precursor cells in the SVZ has been recently reported (O'Keeffe et al., 2009). As dopamine tissue content depends on MAO-B activity (Youdim et al., 2006), the increased MAO-B expression herein evidenced could be related to modulation of that progenitor cell proliferation. If true, MAO-B expression would take place in a further step of nestin/GFAP-positive cell maduration, to limit 
proliferation and facilitate the subsequent differentiation of progenitor cells. In the early AD stages, the increased nestin positive cells paralleled by a marked reduction of GFAP immunoreactivity evidences proliferation of progenitor cells and differentiation to neuroblasts (Kronenberg et al., 2003) or to newborn cells degenerated in the niche of germinal zone. In these conditions, the discrete MAO-B reduction, different from the severe GFAP decrease would reflect the capacity of progenitor cells to adapt to the neurodegenerative process at the SVZ level by increasing their differentiation rate. However, further investigation is required to decipher MAO-B participation in progenitor cells maturation and differentiation in control and neuropathological conditions. Anyhow, MAO-B labeling brings a new reliable tool for SVZ human stem cell study in control and pathological conditions. Finally, because of the marked differences between adult human and other vertebrates SVZ, our work highlights the importance of studying these cells in the human brain, especially when related to CNS diseases.

\section{REFERENCES}

Alvarez-Buylla A, Garcia-Verdugo JM. 2002. Neurogenesis in adult subventricular zone. J Neurosci 22: 629-634.

Arai R, Kimura H, Maeda T. 1986. Topographic atlas of monoamine oxidase containing neurons in the rat brain studied by an improved histochemical method. Neuroscience 19: $905-925$.

Bernier PJ, Bedard A, Vinet J, Levesque M, Parent A. 2002. Newly generated neurons in the amygdala and adjoining cortex of adult primates. Proc Natl Acad Sci USA 99: 11464-11469. 
Bernier PJ, Vinet J, Cossette M, Parent A. 2000. Characterization of the subventricular zone of the adult human brain: evidence for the involvement of Bcl-2. Neurosci Res 37: 67-78.

Blumcke I, Schewe JC, Normann S, Brustle O, Schramm J, Elger CE, Wiestler OD. 2001. Increase of nestin-immunoreactive neural precursor cells in the dentate gyrus of pediatric patients with early-onset temporal lobe epilepsy. Hippocampus 11: 311321.

Braak H, Braak E. 1991. Neuropathological stageing of Alzheimer-related changes. Acta Neuropathol 82: 235-259.

Christie BR, Cameron HA. 2006. Neurogenesis in the adult hippocampus. Hippocampus 16: 199-207.

Doetsch F, Caille I, Lim DA, Garcia-Verdugo JM, Alvarez-Buylla A. 1999. Subventricular zone astrocytes are neural stem cells in the adult mammalian brain. Cell 97: 703-716.

Doetsch F, Garcia-Verdugo JM, Alvarez-Buylla A. 1997. Cellular composition and three-dimensional organization of the subventricular germinal zone in the adult mammalian brain. J Neurosci 17: 5046-5061.

Emilsson L, Saetre P, Balciuniene J, Castensson A, Cairns N, Jazin EE. 2002. Increased monoamine oxidase messenger RNA expression levels in frontal cortex of Alzheimer's disease patients. Neurosci Lett 326: 56-60.

Felling RJ, Levison SW. 2003. Enhanced neurogenesis following stroke. J Neurosci Res 73: $277-283$. 
Garcia AD, Doan NB, Imura T, Bush TG, Sofroniew MV. 2004. GFAP-expressing progenitors are the principal source of constitutive neurogenesis in adult mouse forebrain. Nat Neurosci 7: 1233-1241.

Gross CG. 2000. Neurogenesis in the adult brain: death of a dogma. Nat Rev Neurosci 1: 67-73.

Ihrie RA, Alvarez-Buylla A. 2008. Cells in the astroglial lineage are neural stem cells. Cell Tissue Res 331: 179-191.

Imura T, Kornblum HI, Sofroniew MV. 2003. The predominant neural stem cell isolated from postnatal and adult forebrain but not early embryonic forebrain expresses GFAP. J Neurosci 23: 2824-2832.

Jackson EL, Alvarez-Buylla A. 2008. Characterization of adult neural stem cells and their relation to brain tumors. Cells Tissues Organs 188: 212-224.

Jin K, Peel AL, Mao XO, Xie L, Cottrell BA, Henshall DC, Greenberg DA. 2004. Increased hippocampal neurogenesis in Alzheimer's disease. Proc Natl Acad Sci USA 101: 343-347.

Kennedy BP, Ziegler MG, Alford M, Hansen LA, Thal LJ, Masliah E. 2003. Early and persistent alterations in prefrontal cortex MAO A and B in Alzheimer's disease. J Neural Transm 110: 789-801.

Kokaia Z, Lindvall O. 2003. Neurogenesis after ischaemic brain insults. Curr Opin Neurobiol 13: 127-132.

Konradi C, Kornhuber J, Froelich L, Fritze J, Heinsen H, Beckmann H, Schulz E, Riederer P. 1989. Demonstration of monoamine oxidase-A and -B in the human brainstem by a histochemical technique. Neuroscience 33: 383-400. 
Konradi C, Svoma E, Jellinger K, Riederer P, Denney R, Thibault J. 1988. Topographic immunocytochemical mapping of monoamine oxidase-A, monoamine oxidase-B and tyrosine hydroxylase in human post-mortem brain. Neuroscience 26: 791-802.

Kornack DR, Rakic P. 2001. The generation, migration, and differentiation of olfactory neurons in the adult primate brain. Proc Natl Acad Sci USA 98: 4752-4757.

Kronenberg G, Reuter K, Steiner B, Brandt MD, Jessberger S, Yamaguchi M, Kempermann G. 2003. Subpopulations of proliferating cells of the adult hippocampus respond differently to physiologic neurogenic stimuli. J Comp Neurol 467: 455-463.

Kumar MJ, Andersen JK. 2004. Perspectives on MAO-B in aging and neurological disease: where do we go from here? Mol Neurobiol 30: 77-89.

Levison S, Goldman J. 1993. Both oligodendrocytes and astrocytes develop from progenitors in the subventricular zone of postnatal rat forebrain. Neuron 10: 201-212.

Lie DC, Song H, Colamarino SA, Ming GL, Gage FH. 2004. Neurogenesis in the adult brain: new strategies for central nervous system diseases. Annu Rev Pharmacol Toxicol 44: 399-421.

Lin RC, Matesic DF, Marvin M, McKay RD, Brustle O. 1995. Re-expression of the intermediate filament nestin in reactive astrocytes. Neurobiol Dis 2: 79-85.

Lledo PM, Merkle FT, Alvarez-Buylla A. 2008. Origin and function of olfactory bulb interneuron diversity. Trends Neurosci 31: 392-400.

Merkle FT, Tramontin AD, Garcia-Verdugo JM, Alvarez-Buylla A. 2004. Radial glia give rise to adult neural stem cells in the subventricular zone. Proc Natl Acad Sci USA 101: 17528-17532. 
Mizuno Y, Ohama E, Hirato J, Nakazato Y, Takahashi H, Takatama M, Takeuchi T, Okamoto K. 2006. Nestin immunoreactivity of Purkinje cells in Creutzfeldt-Jakob disease. J Neurol Sci 246: 131-137.

Nakamura S, Kawamata T, Akiguchi I, Kameyama M, Nakamura N, Kimura T. 1990. Expression of monoamine oxidase B activity in astrocytes of senile plaques. Acta Neuropathol 80: 319-325.

Newell KL, Hyman BT, Growdon JH, Hedley-Whyte ET. 1999. Application of the National Institute on Aging (NIA)-Reagan Institute criteria for the neuropathological diagnosis of Alzheimer disease. J Neuropathol Exp Neurol 58: 1147-1155.

O'Keeffe GC, Tyers P, Aarsland D, Dalley JW, Barker RA, Caldwell MA. 2009. Dopamine-induced proliferation of adult neural precursor cells in the mammalian subventricular zone is mediated through EGF. Proc Natl Acad Sci USA 106: 87548759

Quinones-Hinojosa A, Chaichana K. 2007. The human subventricular zone: A source of new cells and a potential source of brain tumors. Exp Neurol 205: 313-324.

Quinones-Hinojosa A, Sanai N, Soriano-Navarro M, Gonzalez-Perez O, Mirzadeh Z, Gil-Perotin S, Romero-Rodriguez R, Berger MS, Garcia-Verdugo JM, AlvarezBuylla A. 2006. Cellular composition and cytoarchitecture of the adult human subventricular zone: a niche of neural stem cells. J Comp Neurol 494: 415-434.

Rodríguez MJ, Saura J, Finch CC, Mahy N, Billett EE. 2000. Localization of monoamine oxidase $\mathrm{A}$ and $\mathrm{B}$ in human pancreas, thyroid, and adrenal glands. J Histochem Cytochem 48: 147-151.

Sanai N, Tramontin AD, Quinones-Hinojosa A, Barbaro NM, Gupta N, Kunwar S, Lawton MT, McDermott MW, Parsa AT, Manuel-Garcia VJ, Berger MS, Alvarez- 
Buylla A. 2004. Unique astrocyte ribbon in adult human brain contains neural stem cells but lacks chain migration. Nature 427: 740-744.

Saura J, Andrés N, Andrade C, Ojuel J, Eriksson K, Mahy N. 1997. Biphasic and region-specific MAO-B response to aging in normal human brain. Neurobiol Aging 18: $497-507$.

Saura J, Luque JM, Cesura AM, Da Prada M, Chan Palay V, Huber G, Löffler J, Richards JG. 1994. Increased monoamine oxidase B activity in plaque-associated astrocytes of Alzheimer brains revealed by quantitative enzyme radioautography. Neuroscience 62: 15-30.

Schnell SA, Staines WA, Wessendorf MW. 1999. Reduction of lipofuscin-like autofluorescence in fluorescently labeled tissue. J Histochem Cytochem 47: 719-730.

Taupin P. 2006. Neurogenesis in the adult central nervous system. C R Biol 329: 465475.

Waldau B, Shetty AK. 2008. Behavior of neural stem cells in the Alzheimer brain. Cell Mol Life Sci.

Wei LC, Shi M, Chen LW, Cao R, Zhang P, Chan YS. 2002. Nestin-containing cells express glial fibrillary acidic protein in the proliferative regions of central nervous system of postnatal developing and adult mice. Brain Res Dev Brain Res 139: 9-17.

Yeomanson KB, Billett EE. 1992. An enzyme immunoassay for the measurement of human monoamine oxidase B protein. Biochim Biophys Acta 1116: 261-268.

Youdim MB, Edmondson D, Typton KF. 2006. The therapeutic potencial of monoamine oxidase inhibitors. Nat Rev Neurosci 7: 295-309. 
Ziabreva I, Perry E, Perry R, Minger SL, Ekonomou A, Przyborski S, Ballard C. 2006. Altered neurogenesis in Alzheimer's disease. J Psychosom Res 61: 311-316.

\section{FIGURE LEGENDS}

Figure 1: Histological characterization of human SVZ in AD cases. (a, b) AD stage VI; Nissl staining showed the anterior horn region and body of ventricle region with a characteristic layer organization. The ependymal cells formed layer I, whereas layer II, a hypocellular region formed a gap with layer III that was organized as a dense ribbon of cell bodies. Finally layer IV represented a transitional zone to the striatal brain parenchyma. c) AD stage II; GFAP immunostaining of showed layer II as the most GFAP-immunoreactive area, with the GFAP immunopositive cell bodies localized in layer III. d) AD stage VI; nestin immunopositive cells were localized mainly in layer III (arrowheads) sometimes formed small chains, with short processes oriented radially to the hypocellular layer. e) AD stage II; scarcely activated microglial cells detected by HLA-DR immunohistochemistry were found mainly in the layer II (arrowhead). Microglial positive cells were also detected in the transitional zone (asterisk) (Layer IV) and brain parenchyma. f) AD stage II; cerebral A $\beta$ protein deposition was practically absent in the human SVZ, except in AD stage VI cases where small amyloid deposits were detected in layer III. In AD cases amyloid-beta deposition was abundantly present in the brain parenchyma. LV: Lateral ventricle. Scale bar: a-e $50 \mu \mathrm{m}$; f, $200 \mu \mathrm{m}$

Figure 2: Evidences of MAO-B localization in the SVZ of AD cases. (a) Quantitative $\left[{ }^{3} \mathrm{H}\right]$ lazabemide in vitro autoradiography of human basal ganglia samples evidenced the highest brain MAO-B labeling in the SVZ (arrow) (Results extracted from Saura et al. 1997). (b) AD stage V; histochemistry showed MAO-B activity labeling in the SVZ, 
especially in astrocytes of layer III (arrows and inset). (c) AD stage V; MAO-B immunohistochemistry counterstained with haematoxylin (cellular nuclei stained in blue) in the SVZ and parenchyma evidenced MAO-B staining (brown) in the cells with astrocyte morphology. (d) MAO-B western blot analysis of the SVZ and striatal parenchyma (parem) brain samples. (e-h) Scater plot and histograms of cell counts from the different markers included in the study, in control subjects $(n=3)$ and AD subjects $(n=7)$. Note the different AD-induced change between Nestin positive cell count and GFAP or MAO-B positive cell counts. LV: Lateral ventricle. AD, Alzheimer's disease. Scale bars: a, $3 \mathrm{~mm}, \mathrm{~b}, 50 \mu \mathrm{m}$; c and inset in b, $15 \mu \mathrm{m} * \mathrm{p}<0.05 ; * * \mathrm{p}<0.01 ; * * *$ $\mathrm{p}<0.001$ vs. control (LSD post-hoc).

Figure 3: Estimation of the AD changes in the relationship between Nestin, GFAP, MAO-B, and HLA-DR positive cell counts in the SVZ. The ratio estimation and dispersion plot of Nestin/GFAP (a,b), Nestin/MAO-B (c,d), GFAP/MAO-B (e,f), and Nestin/HLA-DR (g,h) immunopositive cells evidenced an AD-associated decrease of GFAP-immunopositive cells with respect to both Nestin and MAO-B positive cells. Please note an AD-stage associated increase of nestin positive cells ( $\mathrm{r} 2=0.593, \mathrm{p}=$ 0.038) in dispersion plots b, $\mathrm{d}$ and h. AD, Alzheimer's disease; Stage II and Stage V-VI refers to Stages of AD cases. * $\mathrm{p}<0.05$; vs. control (LSD post-hoc).

Figure 4: Co-localization of SVZ markers of AD cases. (a-c) AD stage V; the double confocal immunohistochemistry of body of ventricle showing GFAP in green and nestin in red, revealed the presence of oval or fusiform astrocyte-like cells mostly in layer III (merge), with positive large and extensive with no special organization. (d-f) AD stage VI; the double confocal nestin (red) / MAO-B (green) immunohistochemistry revealed 
the presence of round-shape cells and unipolar and bipolar cells in layer III and the transitional zone and striatal brain parenchyma (merge) especially in AD samples. (g-i) In control samples the presence of nestin (red) / MAO-B (green) positive large cells with stellate morphology were detected in layer III and in the hypocellular layer nearby blood vessels (merge). Scale bar: a-f, $40 \mu \mathrm{m} ; \mathrm{g}-\mathrm{i}, 16 \mu \mathrm{m}$. 
Table 1: Summary of case histories and cellular composition of the adult human SVZ.

\begin{tabular}{|c|c|c|c|c|c|c|c|c|c|}
\hline & Case $\mathrm{n}^{\circ}$ & $\begin{array}{c}\text { Age } \\
\text { (years) }\end{array}$ & Sex & $\begin{array}{l}\text { Post-mortem } \\
\text { delay (hours) }\end{array}$ & $\begin{array}{c}\text { Neuropathological } \\
\text { diagnosis }\end{array}$ & $\begin{array}{c}\text { Nestin } \\
\text { positive } \\
\text { cells } / \mathrm{mm}^{2} \\
\end{array}$ & $\begin{array}{c}\text { GFAP } \\
\text { positive } \\
\text { cells } / \mathrm{mm}^{2} \\
\end{array}$ & $\begin{array}{c}\text { MAO-B } \\
\text { positive } \\
\text { cells } / \mathrm{mm}^{2} \\
\end{array}$ & $\begin{array}{c}\text { HLA-DR } \\
\text { positive } \\
\text { cells/mm } / \mathrm{mm}^{2}\end{array}$ \\
\hline 1. & BK 331 & 44 & M & 6.0 & Control & $160 \pm 11$ & $187 \pm 51$ & $117 \pm 28$ & $86 \pm 19$ \\
\hline 2. & BK 380 & 72 & $\mathrm{~F}$ & 6.0 & Control & $160 \pm 12$ & $193 \pm 73$ & $120 \pm 10$ & $79 \pm 21$ \\
\hline 3. & BK 499 & 74 & $\mathrm{~F}$ & 3.40 & Control & $157 \pm 28$ & $187 \pm 56$ & $117 \pm 25$ & $76 \pm 22$ \\
\hline 4. & BK 470 & 82 & $\mathrm{~F}$ & 5.45 & AD stage II & $180 \pm 45$ & $70 \pm 26$ & $90 \pm 10$ & $89 \pm 15$ \\
\hline 5. & BK 542 & 79 & $\mathrm{~F}$ & 5.0 & AD stage II & $180 \pm 30$ & $77 \pm 15$ & $93 \pm 28$ & $75 \pm 15$ \\
\hline 6. & BK 569 & 88 & $\mathrm{~F}$ & 4.0 & AD Stage II & $187 \pm 35$ & $53 \pm 25$ & $101 \pm 10$ & $84 \pm 4$ \\
\hline 7. & BK 731 & 91 & M & 7.0 & AD stage $\mathrm{V}$ & $150 \pm 45$ & $93 \pm 11$ & $100 \pm 26$ & $67 \pm 16$ \\
\hline 8. & BK 647 & 90 & $\mathrm{~F}$ & 18.50 & AD stage VI & $253 \pm 35$ & $123 \pm 25$ & $93 \pm 5$ & $71 \pm 10$ \\
\hline 9. & BK 725 & 81 & M & 7.30 & AD stage VI & $313 \pm 72$ & $83 \pm 15$ & $107 \pm 11$ & $83 \pm 12$ \\
\hline 10. & BK 729 & 77 & $\mathrm{~F}$ & 14.0 & AD stage VI & $260 \pm 20$ & $80 \pm 26$ & $88 \pm 10$ & $74 \pm 8$ \\
\hline
\end{tabular}

$\mathrm{M}=$ male; F=female; AD: Alzheimer's disease; MAO-B positive data are from immunohistochemistry study; values are expressed as mean \pm SD 

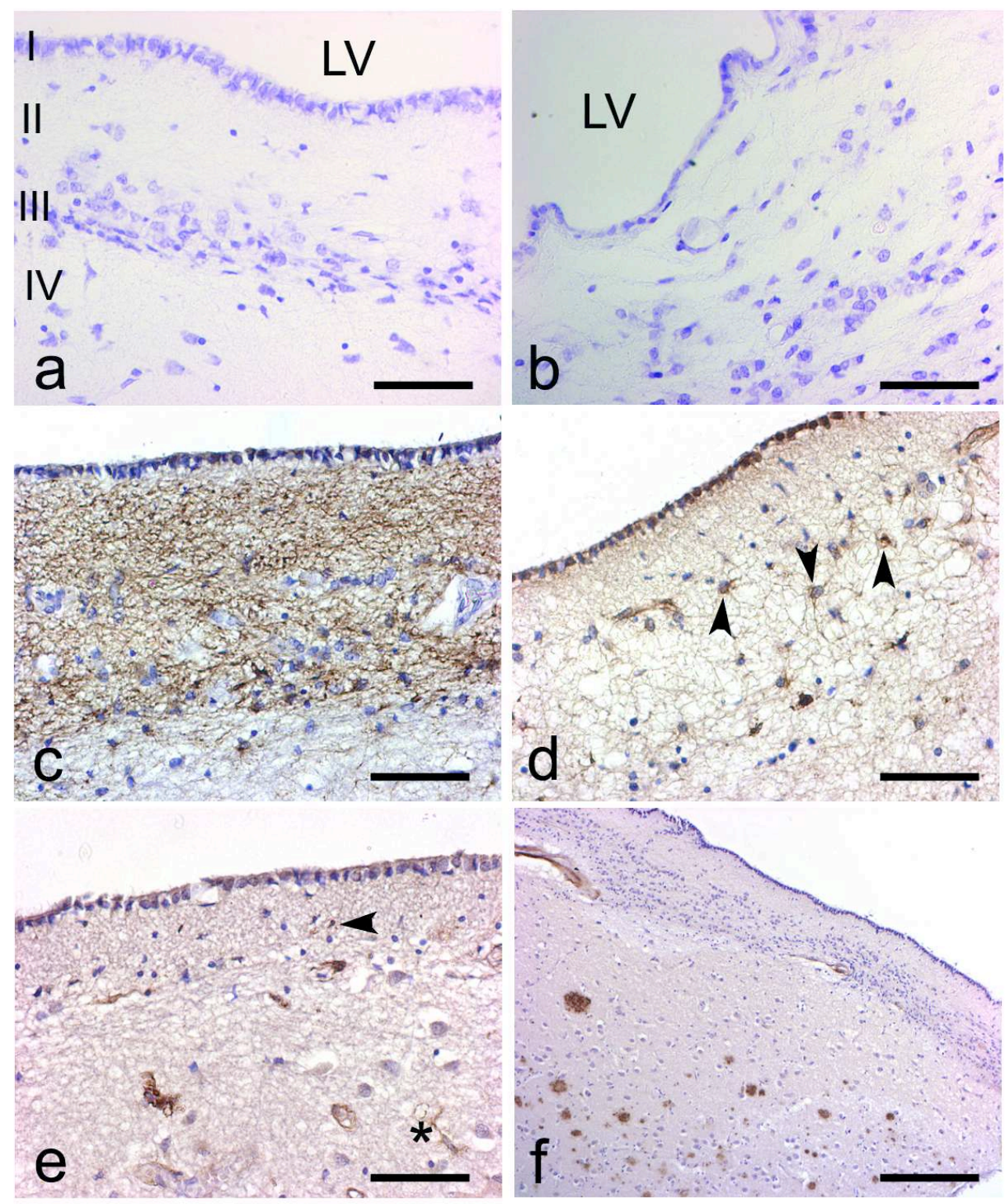

Histological characterization of human SVZ in AD cases $104 \times 124 \mathrm{~mm}$ (300 x $300 \mathrm{DPI})$ 

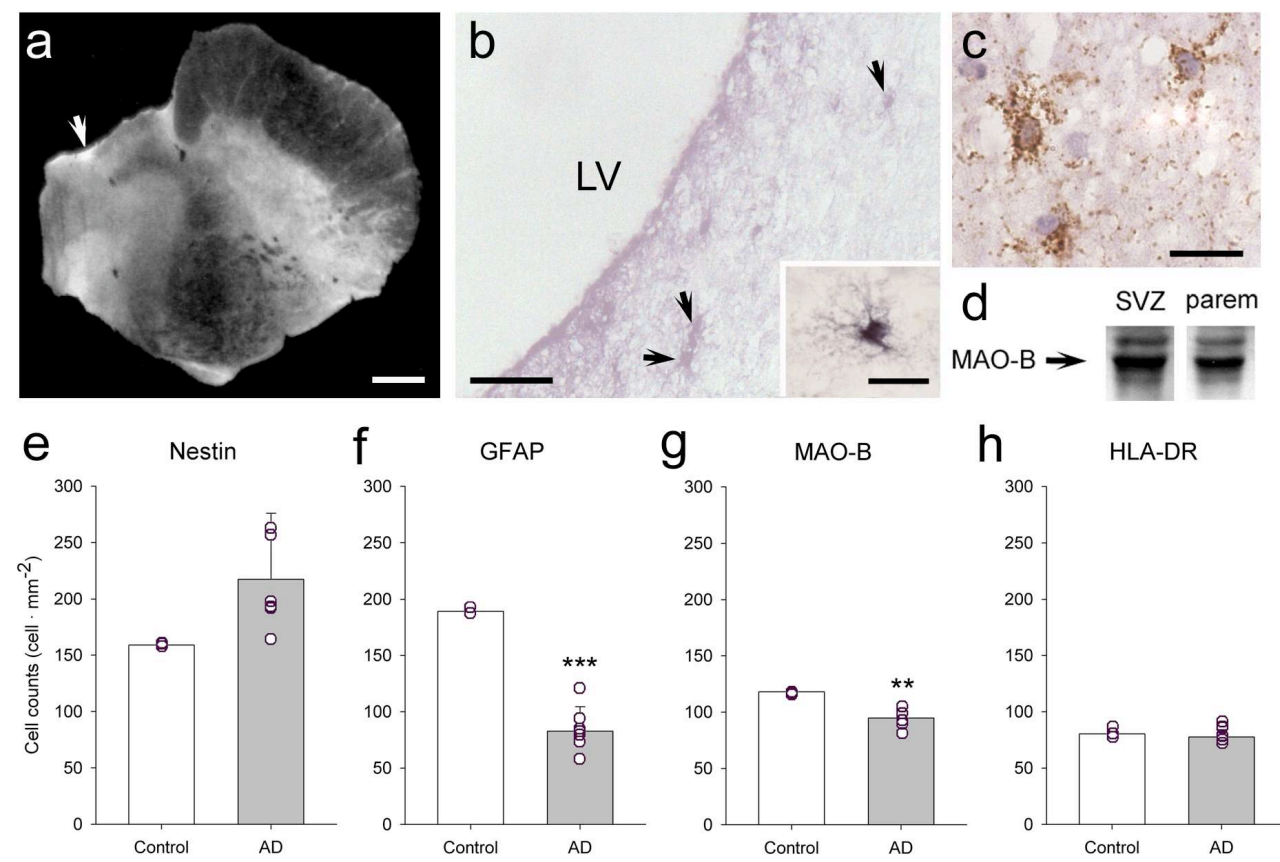

h HLA-DR

Evidences of MAO-B localization in the SVZ of AD cases $160 \times 113 \mathrm{~mm}(300 \times 300 \mathrm{DPI})$ 

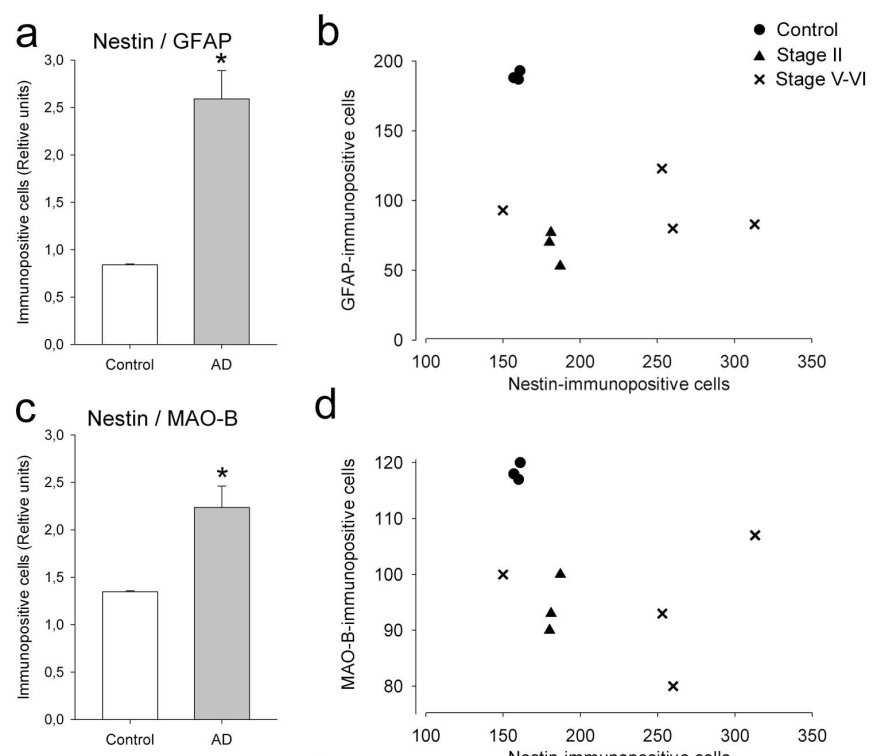

d
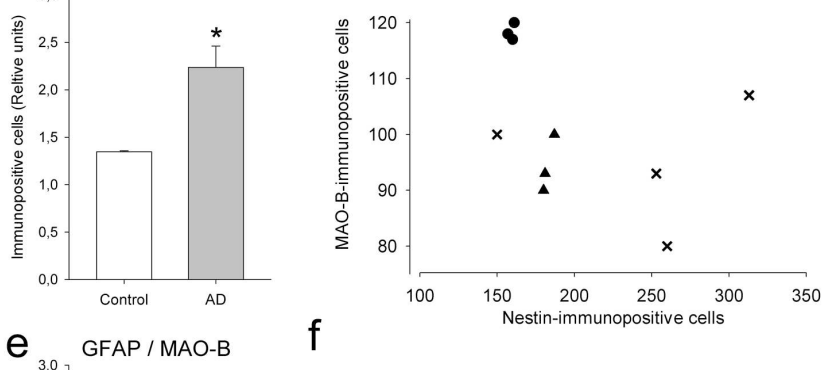

f
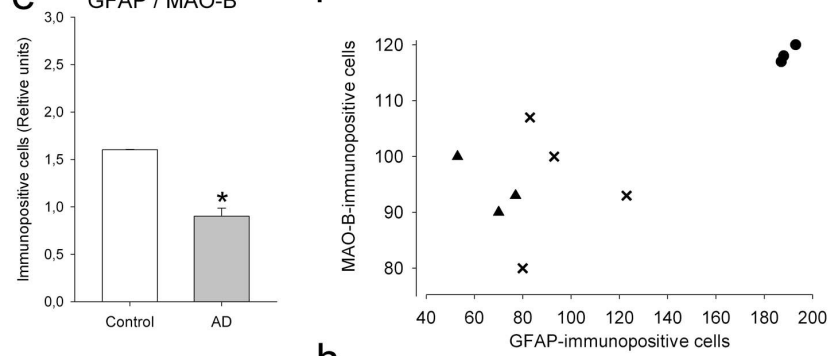

$g$ Nestin/HLA-DR $\mathrm{h}$

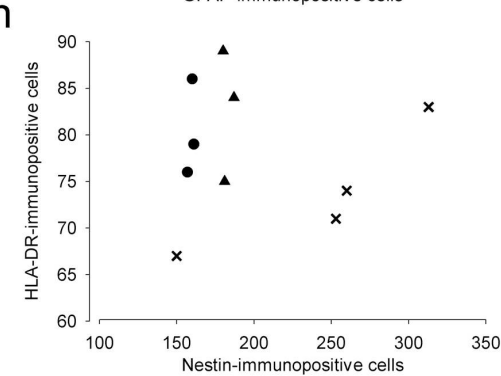

Estimation of the AD changes in the relationship between Nestin, GFAP, MAO-B, and HLA-DR positive cell counts in the SVZ

$129 \times 230 \mathrm{~mm}(300 \times 300 \mathrm{DPI})$ 

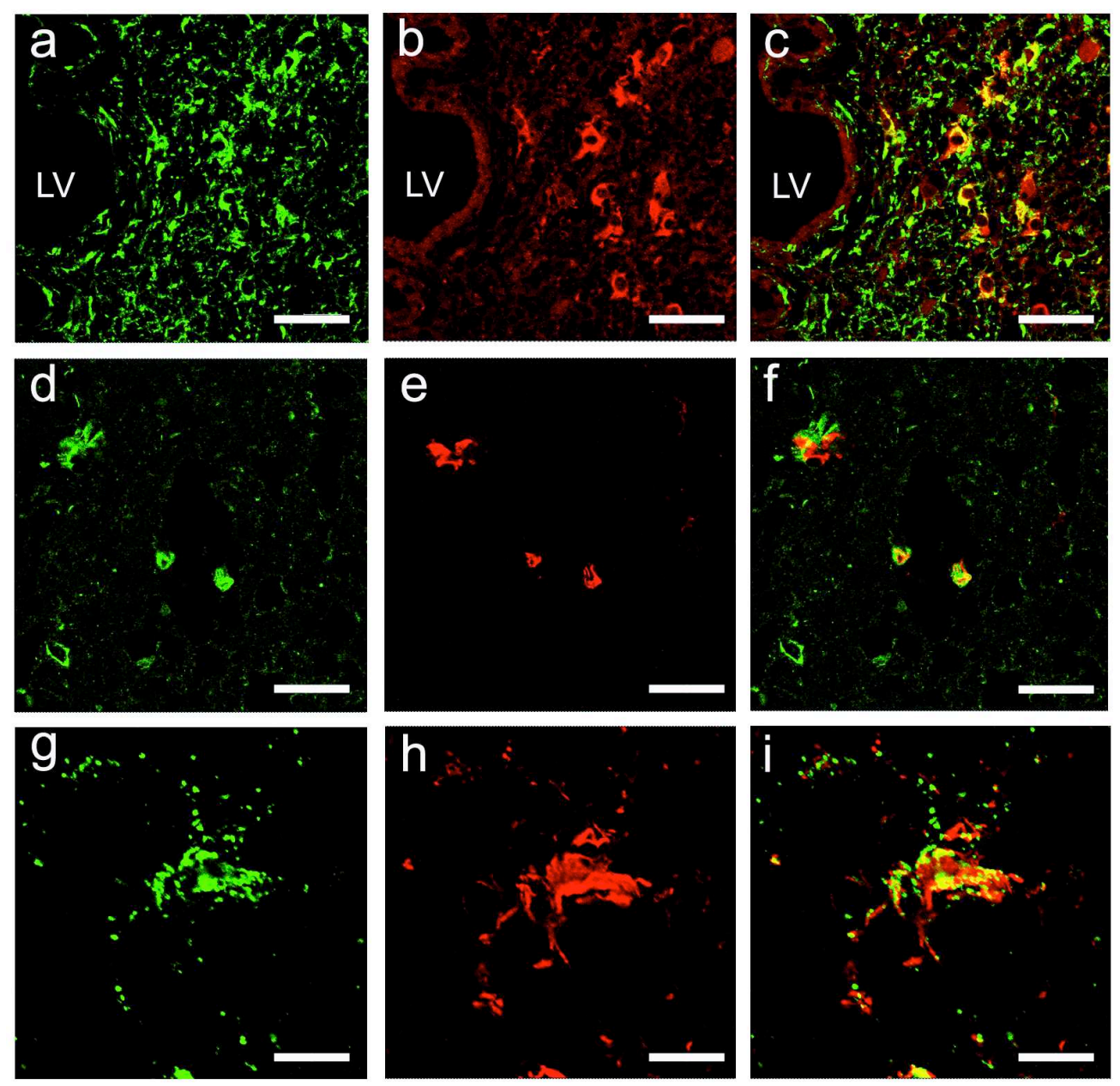

Co-localization of SVZ markers in AD cases $136 \times 134 \mathrm{~mm}(300 \times 300 \mathrm{DPI})$ 